\title{
Article \\ Speciation of $P$ in Solid Organic Fertilisers from Digestate and Biowaste
}

\author{
Inge C. Regelink ${ }^{1}$, Caleb E. Egene ${ }^{2, * \mathbb{D}}$, Filip M. G. Tack ${ }^{2} \mathbb{D}$ and Erik Meers ${ }^{2}$ (D) \\ 1 Wageningen Environmental Research, Wageningen University and Research (WUR), 6708 PB Wageningen, \\ The Netherlands; inge.regelink@wur.nl \\ 2 Department of Green Chemistry and Technology, Faculty of Bioscience Engineering, Ghent University, \\ Coupure Links 653, 9000 Ghent, Belgium; filip.tack@ugent.be (F.M.G.T.); erik.meers@ugent.be (E.M.) \\ * Correspondence: calebelijah.egene@ugent.be
}

Citation: Regelink, I.C.; Egene, C.E.; Tack, F.M.G.; Meers, E. Speciation of P in Solid Organic Fertilisers from Digestate and Biowaste. Agronomy 2021, 11, 2233. https://doi.org/ 10.3390 /agronomy11112233

Academic Editor: Hans-Werner Olfs

Received: 14 September 2021

Accepted: 31 October 2021

Published: 4 November 2021

Publisher's Note: MDPI stays neutral with regard to jurisdictional claims in published maps and institutional affiliations.

Copyright: (c) 2021 by the authors. Licensee MDPI, Basel, Switzerland. This article is an open access article distributed under the terms and conditions of the Creative Commons Attribution (CC BY) license (https:// creativecommons.org/licenses/by/ $4.0 /)$.

\begin{abstract}
Phosphorus $(\mathrm{P})$ is a finite resource and its reuse in organic fertilisers made from biowaste and manure should therefore be encouraged. The composition of solid organic fertilisers (SOFs) depends on the type of feedstock and processing conditions, and this may affect $\mathrm{P}$ speciation and hence $P$ availability. Phosphorus speciation was assessed in eighteen different SOFs produced from biowaste and digestate. Available $\mathrm{P}$ was determined in $10 \mathrm{mM} \mathrm{CaCl}_{2}$ extracts at a fixed $\mathrm{pH}$ of 5.5 and at a fixed total $\mathrm{P}$ concentration in the suspension. P was dominantly present as inorganic $\mathrm{P}$ ( $>80 \%$ of total $\mathrm{P})$. There was a strong variation in the Fe content of the SOFs and hence in the fraction of $\mathrm{P}$ bound to reactive $\mathrm{Fe} / \mathrm{Al}$-oxides $\left(\mathrm{P}_{\mathrm{Fe}}\right)$. The fraction of total $\mathrm{P}$ soluble at $\mathrm{pH} 5.5$ correlated negatively with $\mathrm{P}_{\mathrm{Fe}}$ pointing to fixation of $\mathrm{P}$ by metal salts added during processing, or by soil mineral particles in case garden waste was processed. Therefore, the use of iron salts in processing plants should be avoided. In addition, the presence of $\mathrm{P}$ in poorly soluble precipitates lowered the fraction of easily available $\mathrm{P}$. Overall, this study shows that $\mathrm{P}_{\mathrm{t}}$ alone is not a good indicator for the agronomic efficiency of SOFs due to large differences in $\mathrm{P}$ speciation among SOFs.
\end{abstract}

Keywords: manure; solid fraction of digestate; compost; phosphorus; iron salts

\section{Introduction}

Most of the phosphorus (P) used in agriculture today is derived from the mining of nonrenewable phosphate rock. However, global $P$ reserves are rapidly being depleted [1] thus raising important questions about the long-term supply security of $\mathrm{P}$ [2]. Recovery and recycling of $\mathrm{P}$ are vital for sustaining long-term food production as over $90 \%$ of current $P$ resources are used as fertilisers [1,3]. Biowaste from consumers and food processing industries forms a large yet mostly unexploited resource of P [4]. Food waste is the second largest flow of P losses in the EU after sewage sludge from communal wastewater treatment plants [4]. Animal manure is another large resource of $\mathrm{P}$ which is, in areas with a surplus of animal manure, often used in excess as compared to crop uptake resulting in accumulation of $\mathrm{P}$ in soils and runoff to surface water [4]. Processing biowaste and manure into safe and agronomically efficient fertilisers that can replace the current use of $\mathrm{P}$ fertilisers from fossil resources is, therefore, essential.

Solid organic fertilisers (SOFs) include a wide array of biobased products that are characterized by high organic matter contents and moderate to high amounts of organic and/or inorganic P. Common SOFs typically used in agriculture include the solid fraction (SF) of animal manure $[5,6]$, raw or mechanically separated digestate from anaerobic digestion (AD) of animal manure, energy crops and food waste [7-9], composts and garden waste $[10,11]$, among others. In practice, the choice of which SOF to use as a P source is often based on their total P content. However, this may not be indicative of the plantavailable $\mathrm{P}$ content of the SOFs. The availability of $\mathrm{P}$ depends on its speciation, which may vary among SOFs depending on feedstock composition and the type of processing 
treatments applied [12-14]. Since plants can only utilise P in inorganic form, speciation and solubility of the inorganic $P$ is most relevant in terms of plant-availability. Inorganic $P$ is often associated with multivalent cations forming phosphate salts including brushite $\left(\mathrm{CaHPO}_{4} \cdot 2 \mathrm{H}_{2} \mathrm{O}\right)$ and struvite $\left(\mathrm{MgNH}_{4} \mathrm{PO}_{4} \cdot 6 \mathrm{H}_{2} \mathrm{O}\right)$ [15]. These precipitates typically dissolve under slightly acidic conditions thereby releasing orthophosphate $\left(\mathrm{P}_{-} \mathrm{PO}_{4}\right)[16,17]$. Of particular importance are levels of $\mathrm{Fe}$ and $\mathrm{Al}$ in the SOF since $\mathrm{P}$ is preferentially bound to these metals either through precipitation as, for example, vivianite $\left(\mathrm{Fe}_{3}\left(\mathrm{PO}_{4}\right)_{2} \cdot 8 \mathrm{H}_{2} \mathrm{O}\right)$ [18] or through adsorption onto the surfaces of amorphous Fe and Al-oxides $[10,19,20]$ thereby controlling soluble P concentrations at a low level even under slightly acidic conditions. Elevated concentrations of Fe or Al in the SFs of digestates have been linked to the addition of Fe- or Al-based precipitating agents during feedstock processing [14,21] to control $\mathrm{H}_{2} \mathrm{~S}$ production [22] or to improve the separation efficiency for organic substances and P during solid-liquid separation [23]. Additionally, the use of feedstocks containing high levels of mineral particles, such as garden waste and iron-rich flotation sludges from industrial wastewater treatment plants (WWTP), may contribute to high levels of Fe and Al in SOFs. There is, therefore, a need to assess $\mathrm{P}$ speciation and levels of easily available P in SOFs, and in particular in relation to $\mathrm{Fe}$ and $\mathrm{Al}$ contents.

Ammonium-oxalate (oxalate) extraction [24] is conventionally used to differentiate between reactive pools of $\mathrm{Fe}, \mathrm{Al}$, and $\mathrm{P}\left(\mathrm{Al}_{\mathrm{ox}}, \mathrm{Fe}_{\mathrm{ox}}\right.$, and $\mathrm{P}_{\mathrm{ox}}$, respectively) and the more stable, nonreactive pools. Total Fe, for example, may represent multiple iron minerals including structurally bound Fe in clay minerals, crystalline Fe-(hydr)oxides (e.g., goethite) and amorphous Fe hydroxides (e.g., ferrihydrite), and these Fe minerals strongly differ in terms of $\mathrm{P}$ binding capacity. Therefore, in order to assess the $\mathrm{P}$ binding capacity of a $\mathrm{P}$ source, $\mathrm{Fe}_{\mathrm{ox}}$ and $\mathrm{Al}_{\mathrm{ox}}$ are more informative since the oxalate extraction procedure targets only small and amorphous Fe and Al-(hydr)oxides with a high capacity for adsorption of $\mathrm{P}$. Similarly, $\mathrm{P}_{\mathrm{ox}}$ represents the $\mathrm{P}$ fraction that is associated with Fe/Al-oxides. However, this assumption only holds for soils or organic products containing high amounts of soil particles such as compost. It is worth noting that the $\mathrm{P}_{\mathrm{ox}}$ extraction method also extracts acid-soluble $\mathrm{P}$ forms including struvite and calcium phosphate meaning that $\mathrm{P}_{\text {ox }}$ may overestimate the amount of $\mathrm{P}$ bound to Fe/Al-oxides in SOFs with a high $\mathrm{P}_{\text {ox }}$ and low $\mathrm{Fe}_{\mathrm{ox}}$ content. This distinction is important since $\mathrm{Fe}_{\mathrm{ox}}, \mathrm{Al}_{\mathrm{ox}}$, and $\mathrm{P}_{\mathrm{ox}}$ concentrations are often used as indicators for predicting $\mathrm{P}$ availability [25-28].

Earlier studies have evaluated different chemical extractions for predicting $\mathrm{P}$ availability in SOFs but results have been inconclusive for a variety of reasons. Elliot et al. [29] assessed the use of neutral ammonium-citrate-soluble $\mathrm{P}\left(0.88 \mathrm{M}\right.$ citrate solution at $\left.65^{\circ} \mathrm{C}\right)$ to estimate plant-available $\mathrm{P}$ in SOFs but found that it could not distinguish between directly available $\mathrm{P}$ and $\mathrm{P}$ bound to Fe/Al-oxides due to dissolution of the latter metals. Meyer et al. [13] found that a water extraction underestimated, while the citric acid extraction overestimated, the plant-available P in recycled fertilisers. Janßen [30] criticized the use of the CAT extraction method (10 $\left.\mathrm{mM} \mathrm{CaCl}_{2}+2 \mathrm{mM} \mathrm{DTPA}\right)$ for determining easily available $\mathrm{P}_{-} \mathrm{PO}_{4}$ in soil improvers for being insensitive to small differences in the composition of materials under investigation, which may lead to overestimation of the available $\mathrm{P}$, especially in materials with high $\mathrm{pH}$. The use of extraction solutions containing chelates (e.g., citrate, DTPA) overestimates the fraction of easily available P due to the dissolution of Fe/Al-oxides. This can be prevented by using a mild salt solution or demineralized water as an extractant. For instance, extraction with $10 \mathrm{mM} \mathrm{CaCl}_{2}$ has been widely used to relate easily available P in SOFs [31,32] and SOF-amended soils [33-36] to plant-available P. However, it was found that water-extractable $\mathrm{P}$ in compost decreased with increasing $\mathrm{pH}$ due to the $\mathrm{pH}$-dependent solubility of phosphate salts [36].

The issues related to the use of the aforementioned methods suggest that two important factors control their reliability when comparing $\mathrm{P}$ availability in SOFs. Firstly, at the $\mathrm{pH}$ value of most SOFs $(>7)$, the measured $\mathrm{P}_{-} \mathrm{PO}_{4}$ concentration is the result of the solubility products of $\mathrm{Ca}$ and/or $\mathrm{Mg}$ phosphate salts (calcium phosphate, struvite, etc.). Composts and SFs of digestate usually have a slightly alkaline $\mathrm{pH}$ and this means 
that water-extractable $\mathrm{P}$ levels underestimate the fraction of available $\mathrm{P}$ when the SOF is applied on a soil with a neutral or slightly acidic $\mathrm{pH}$. Secondly, the methods adopt a fixed mass:extractant ratio which means that large differences in total $\mathrm{P}$ content in the SOFs are not accounted for. In that case, for SOFs with a higher P content, less $\mathrm{P}$ will go into solution relative to total $\mathrm{P}$ under conditions where the $\mathrm{P}$ concentration in the extractant is controlled by the solubility product of phosphate salts or by a desorption equilibrium. Brod et al. [37] demonstrated that different SOFs, with different initial pH values, exert varying degrees of influence on the $\mathrm{pH}$ of the extraction solution and this variation was partly explained by mass:extractant ratio used in the extraction. Therefore, a more reliable method for predicting the $\mathrm{P}$ fertilising potential of SOFs should consider the type of $\mathrm{P}$ compounds present in the fertiliser as well as the $\mathrm{pH}$ of the target soil [23].

In practice, the application rate for $\mathrm{P}$ fertilisation is adjusted based on the total $\mathrm{P}$ content of the SOFs. However, the proportion of $\mathrm{P}$ that will go into solution after application is strongly influenced by the $\mathrm{pH}$ of the agricultural soil. Thus, we hypothesized that by evaluating $\mathrm{P}$ availability based on a fixed total $\mathrm{P}$ content in the extraction solution and at uniform $\mathrm{pH}$, artefacts' due differences in the $\mathrm{P}$ content and $\mathrm{pH}$ value of the SOFs will be avoided. Furthermore, the proposed methodology will likely reveal new relationships between available $\mathrm{P}$ and inherent SOF characteristics, which will make it possible to identify indicators that can distinguish differences in $\mathrm{P}$ availability among SOFs.

The purpose of this study was to test a novel approach for assessing $\mathrm{P}$ speciation in eighteen SOFs originating from diverse feedstocks and processing treatments with a specific focus on the use of iron salts or iron-rich feedstocks. The second aim of the study was to establish a relationship between easily available $\mathrm{P}\left(\mathrm{P}-\mathrm{CaCl}_{2}\right)$ and other characteristics of the SOF, including its $\mathrm{Fe}_{\mathrm{ox}}$ content.

\section{Materials and Methods}

\subsection{Origin of the Solid Organic Fertilisers}

In total, eighteen SOFs were collected (Table 1). Ten samples of SF of digestates were obtained from six full-scale anaerobic digestion (AD) plants, six samples of composts and three samples of sieved soils were collected from six biowaste treatment facilities.

Table 1. Origin of the solid organic fertilisers, feedstock and description of feedstock processing ${ }^{\mathrm{a}}$.

\begin{tabular}{|c|c|c|c|c|}
\hline Type & Processing Plant & Code & Feedstock and Processing & Fe-Salts ${ }^{d}$ \\
\hline \multirow{9}{*}{ SF of digestate } & AM-Power ${ }^{b}$ & AMP-SF & $\begin{array}{c}\text { Dried SF of digestate of biowaste } \\
\text { including incl. sludge from } \\
\text { agro-food industry }\end{array}$ & $\mathrm{N}$ \\
\hline & \multirow{2}{*}{ Groot Zevert Vergisting ${ }^{b}$} & GZV-SF1 & $\begin{array}{l}\text { SF of digestate of pig manure and } \\
\text { biowaste }\end{array}$ & $\mathrm{N}$ \\
\hline & & GZV-SF2 & $\begin{array}{l}\text { Low-P SF obtained after leaching } \\
\text { P with water and sulphuric acid }\end{array}$ & $\mathrm{N}$ \\
\hline & \multirow{2}{*}{ Benas ${ }^{b}$} & BNS-SF1 & $\begin{array}{c}\text { SF of digestate of energy crops and } \\
\text { poultry litter }\end{array}$ & $\mathrm{N}$ \\
\hline & & BNS-SF2 & $\begin{array}{c}\text { Low N SF obtained by removing } \\
\text { N through stripping }\end{array}$ & $\mathrm{N}$ \\
\hline & \multirow[t]{2}{*}{ Waterleau New Energy $b$} & WNE-SF1 & $\begin{array}{c}\text { Dried SF of digestate of manure } \\
\text { and biowaste incl. sludge from } \\
\text { agro-food industry }\end{array}$ & $\mathrm{Y}$ \\
\hline & & WNE-SF2 & $\begin{array}{c}\text { Dried SF mixed with concentrated } \\
\text { liquid fraction of digestate }\end{array}$ & $\mathrm{Y}$ \\
\hline & Dairy farm $^{\mathrm{c}}$ & DF-SF & SF of digestate of dairy manure & $\mathrm{N}$ \\
\hline & $\begin{array}{l}\text { Sugar-beet processing } \\
\text { company }\end{array}$ & BP-SF & $\begin{array}{c}\text { SF of digestate of residues from } \\
\text { sugar beets }\end{array}$ & $\mathrm{Y}$ \\
\hline
\end{tabular}


Table 1. Cont.

\begin{tabular}{|c|c|c|c|c|}
\hline Type & Processing Plant & Code & Feedstock and Processing & Fe-Salts $^{d}$ \\
\hline \multirow{6}{*}{ Compost } & \multirow{6}{*}{$\begin{array}{l}\text { Biowaste treatment } \\
\text { facilities }\end{array}$} & VFG-COMP1 & \multirow{2}{*}{$\begin{array}{c}\text { Compost of source separated VFG } \\
\text { waste }\end{array}$} & $\mathrm{N}$ \\
\hline & & VFG-COMP2 & & $\mathrm{N}$ \\
\hline & & VFG-COMP3 & \multirow{2}{*}{$\begin{array}{l}\text { Compost of digestate of source } \\
\text { separated VFG waste. }\end{array}$} & $\mathrm{Y}$ \\
\hline & & VFG-COMP4 & & $\mathrm{Y}$ \\
\hline & & GW-COMP1 & \multirow{2}{*}{ Compost of garden waste } & $\mathrm{N}$ \\
\hline & & GW-COMP2 & & $\mathrm{N}$ \\
\hline \multirow{3}{*}{ Sieved soil } & \multirow{3}{*}{$\begin{array}{l}\text { Biowaste treatment } \\
\text { facilities }\end{array}$} & SOIL1 & \multirow{3}{*}{$\begin{array}{c}\text { Fraction }<2 \mathrm{~mm} \text { obtained by } \\
\text { sieving garden waste prior to } \\
\text { composting }\end{array}$} & $\mathrm{N}$ \\
\hline & & SOIL2 & & $\mathrm{N}$ \\
\hline & & SOIL3 & & $\mathrm{N}$ \\
\hline
\end{tabular}

a SF: solid fraction, AMP: Am-Power, GZV: Groot Zevert Vergisting, BNS: Benas, WNE: Waterleau New Energy, APF: Arjan Prinssen Farm, VFG-COMP: compost of vegetable, fruit and garden (VFG) waste, GW-COMP: compost of garden waste (GW). ${ }^{\mathrm{b}}$ Demonstration plants within the H2020 project SYSTEMIC. ${ }^{c}$ Demonstration plant within the H2020 project FertiManure. ${ }^{\mathrm{d}}$ Fe: the use of iron salts or iron water in the digester or digestate processing facilities, $\mathrm{Y}$; yes, N; no.

AM-Power (AMP, Pittem, Belgium) treats residues from the food processing industry and source-separated food waste via thermophilic $\left(\sim 55^{\circ} \mathrm{C}\right) \mathrm{AD}$ with a retention time of about 60 days. Iron salts are not added but the feedstock includes iron-rich sludge from WWTPs of food processing companies. A decanter is used to separate the digestate into solid and liquid fractions using polymers to improve separation efficiency. The SF is thereafter dried at $60^{\circ} \mathrm{C}$ in a fluidized bed dryer (AMP-SF).

Benas (BNS, Ottersberg, Germany) treats energy crops (silage maize, silage rye and corn, $85 \% w / w)$ and poultry litter $(15 \% w / w)$ using thermophilic digestion. The ammonia content of the digestate is lowered through treatment of a side stream of digestate by means of an $\mathrm{N}$ stripper to control inhibition of biogas formation resulting from ammonia toxification. A screw press was used to separate the SF from the main digestate stream (BNS-SF1). A second SF was collected from a screw press located immediately after the $\mathrm{N}$ stripper resulting in a SF with a reduced $\mathrm{N}$ content (BNS-SF2). BNS-SF2 was air-dried whereas BNS-SF1 was not dried.

Groot Zevert Vergisting (GZV, Beltrum, The Netherlands) operates a mesophilic $\left(\sim 35^{\circ} \mathrm{C}\right)$ AD plant that is fed with pig slurry $(81 \% w / w)$ and food processing residues (a.o. grain and rice husk, potato skins and coffee grounds, $19 \% w / w)$. Digestate is dewatered through a decanter (GZV-SF1) without the use of additives. Part of the SF is further processed in an installation to remove and recover $\mathrm{P}$ which includes washing the SF with water and sulphuric acid to obtain a SF with a reduced $\mathrm{P}$ content and a fibrous structure (GZV-SF2).

Waterleau New Energy (WNE, Ieper, Belgium) operates an AD plant used for the mesophilic $\left(\sim 35^{\circ} \mathrm{C}\right)$ digestion of residues from agroindustry (potatoes and grain, $\left.40 \% w / w\right)$, sludge from industrial WWTPs $(15 \% w / w)$ and animal manure $(45 \% w / w)$. Digestate is passed through a decanter to obtain a SF which is thereafter dried producing a solid organic fertiliser (WNE-SF). Iron sludge (a side product from drinking water production) and $\mathrm{FeCl}_{3}$ salts are added in the $\mathrm{AD}$ and during the separation process to bind $\mathrm{H}_{2} \mathrm{~S}$ and to improve the separation efficiency. The liquid fraction of the digestate was further processed by means of reverse osmosis and evaporation and the $\mathrm{N}+\mathrm{K}$-rich evaporator concentrate was mixed with the dried SF producing a paste-like product (WNE-SF2). WNE, GZV, AMP and BNS are demonstration plants within the EU project SYSTEMIC and more information is available on [38] and in Brienza et al. [39].

The dairy farm (DF, Haarlo, The Netherlands) processes dairy manure $(90 \% w / w)$ and coproducts (beet tips and grass, $10 \% w / w)$ in a mesophilic $\left(\sim 35^{\circ} \mathrm{C}\right) \mathrm{AD}$ followed by $\mathrm{N}$ stripping and solid-liquid separation using a screw press without the use of chemical 
additives. The SF is referred to as DF-SF. This dairy farm is a demonstration plant within the EU project FERTIMANURE [40].

A sugar beet processing company treats residues from sugar beets (beet tips and beet pulp) in a mesophilic AD plant. Iron sludge (a residue from the production of drinking water from groundwater) was added to control $\mathrm{H}_{2} \mathrm{~S}$ emissions and digestate was dewatered by a decanter (BP-SF).

Four compost samples originated from source-separated vegetable fruit and garden (VFG) waste which are here referred to as VFG-COMP1\&2 and VFG-COMP3\&4 where the latter refers to the two plants where VFG waste is digested before composting leading to elevated Fe contents due to the addition of Fe salts during digestion to control $\mathrm{H}_{2} \mathrm{~S}$ emissions. Two composts were produced from garden waste $(\mathrm{GW})$ and are referred to as GW-COMP1 and GW-COMP2.

Three samples of sieved soil were collected from biowaste treatment companies. Sieved soil is defined as the $<2 \mathrm{~mm}$ fraction obtained after sieving garden waste to separate the soil fraction from the organic material. Sieved soils are typically not considered as fertiliser but are included in this study as reference material to compare the availability of $\mathrm{P}$ in organic fertilisers with high amounts of soil fraction in organic waste.

\subsection{Analytical Methods}

\subsubsection{Solid Organic Fertiliser Characterisation}

About $10 \mathrm{~kg}$ of fresh material was homogenized, dried at $40{ }^{\circ} \mathrm{C}$, ground and sieved over $2 \mathrm{~mm}$ and hereafter referred to as 'dried samples'. About $5 \mathrm{~kg}$ of fresh material was stored in a fridge until analyses. Dry weight (DW) was determined of fresh samples after drying at $105^{\circ} \mathrm{C}$ for $24 \mathrm{~h}$. The OM content was determined on dried samples by loss-on-ignition at $550{ }^{\circ} \mathrm{C}$. Total contents of $\mathrm{P}, \mathrm{Ca}, \mathrm{Mg}, \mathrm{K}, \mathrm{S}$ and $\mathrm{Fe}\left(\mathrm{P}_{\mathrm{t}}, \mathrm{Ca}_{\mathrm{t}}, \mathrm{Mg}_{\mathrm{t}}, \mathrm{K}_{\mathrm{t}}\right.$ and $\left.\mathrm{S}_{\mathrm{t}}\right)$ were determined after destruction of dried sample by the aqua regia method followed by analysis of the elemental concentrations using inductively coupled plasma optical emission spectroscopy (ICP-OES) [41]. Total $\mathrm{N}$ was determined using the Kjeldahl method [42]. $\mathrm{pH}$ was determined by extracting fresh samples with $10 \mathrm{mM} \mathrm{CaCl}_{2}$ using a 1:10 $(w / v)$ sample to extractant ratio [43].

\subsubsection{P Extraction Procedures}

An overview of the P-pools evaluated in this study and their respective methods is given in Table 2. The $\mathrm{P}_{\mathrm{t}-\mathrm{kuo}}$ method [44] was used to distinguish between inorganic $\mathrm{P}\left(\mathrm{P}_{\mathrm{io}}\right)$ and organic $\mathrm{P}\left(\mathrm{P}_{\mathrm{o}}\right)$. Inorganic $\mathrm{P}$ was determined by extracting $2 \mathrm{~g}$ of dried sample with $50 \mathrm{~mL}$ of $0.5 \mathrm{M} \mathrm{H}_{2} \mathrm{SO}_{4}$ followed by shaking for $16 \mathrm{~h}$, filtration over $0.45 \mu \mathrm{m}$ and colorimetric measurement of $\mathrm{P}_{-} \mathrm{PO}_{4}$ in the filtrate. Total $\mathrm{P}\left(\mathrm{P}_{\mathrm{t}, \mathrm{kuo}}\right)$ was determined after oxidation of the sample at $550{ }^{\circ} \mathrm{C}$ followed by extraction with $0.5 \mathrm{M} \mathrm{H}_{2} \mathrm{SO}_{4}$ and $\mathrm{P}_{\mathrm{o}}$ was defined as the difference between $\mathrm{P}_{\mathrm{t}, \mathrm{kuo}}$ and $\mathrm{P}_{\mathrm{io}}$.

Oxalate-extractable $\mathrm{P}, \mathrm{Fe}$ and $\mathrm{Al}\left(\mathrm{P}_{\mathrm{ox}}, \mathrm{Fe}_{\mathrm{ox}}, \mathrm{Al}_{\mathrm{ox}}\right)$ were determined by shaking $1 \mathrm{~g}$ of dried sample with $0.2 \mathrm{M}$ ammonium oxalate at $\mathrm{pH} 3.0$ for $4 \mathrm{~h}$ in the dark followed by centrifugation, filtration $(0.45 \mu \mathrm{m})$ and analyses of the filtrate on $\mathrm{P}, \mathrm{Fe}$ and $\mathrm{Al}$ by ICPOES [45].

Easily available $\mathrm{P}$ was determined using an adapted $\mathrm{CaCl}_{2}$ extraction procedure using a predetermined $\mathrm{P}_{\mathrm{t}}$ content in the suspension of $150 \mathrm{mg} \mathrm{P} / \mathrm{L}$. An amount of fresh sample containing $75 \mathrm{mg} P$ was added to $500 \mathrm{~mL} 10 \mathrm{mM} \mathrm{CaCl}_{2}$ solution and horizontally shaken for $30 \mathrm{~min}$. Fresh samples were used to prevent artefacts due to drying. The fixed $\mathrm{P}_{t}$ content prevent artefacts due to strong differences in $\mathrm{P}_{\mathrm{t}}$ between samples. The sample to extraction ratio varied between 6-100 g/L based on DW. After 30 min of shaking, a $30 \mathrm{~mL}$ subsample was taken, centrifuged and filtrated ( $0.45 \mathrm{um}$ membrane filter). The remaining suspension $(470 \mathrm{~mL})$ was thereafter put in a $1 \mathrm{~L}$ beaker glass and stirred using a magnetic stirrer while $0.8 \mathrm{M} \mathrm{H}_{2} \mathrm{SO}_{4}$ was added to decrease the $\mathrm{pH}$ to 5.0. Once a stable $\mathrm{pH}$ was reached, the suspensions were stirred for another $30 \mathrm{~min}$ and thereafter sampled as described above. During the 30 min of shaking, $\mathrm{pH}$ slightly increased towards values between 5.5 and 5.8 . 
All filtrates were analysed on $\mathrm{P}_{-} \mathrm{PO}_{4}, \mathrm{~N}-\mathrm{NH}_{4}$ and $\mathrm{N}-\mathrm{NO}_{3}$ and dissolved organic carbon (DOC) (spectrophotometrically using a segmented flow analyser) and on total $\mathrm{P}, \mathrm{Ca}, \mathrm{Mg}, \mathrm{K}$, $\mathrm{P}, \mathrm{Fe}$ and Al by ICP-OES (Thermo Fisher Scientific, iCAP 6500 duo, Waltham, MA, USA). Total $\mathrm{P}$ in $\mathrm{CaCl}_{2}$ is referred to as $\mathrm{P}-\mathrm{CaCl}_{2}$ (at the initial $\mathrm{pH}$ ) and $\mathrm{P}-\mathrm{CaCl}_{2, \mathrm{pH} 5 \cdot 5}$ (at $\mathrm{pH}$ 5.5). Organic $\mathrm{P}$ in the $\mathrm{CaCl}_{2}$-extracts is defined as the difference between total $\mathrm{P}$ (ICP-OES) and $\mathrm{P}_{-} \mathrm{PO}_{4}$. The $\mathrm{CaCl}_{2}$ extraction was performed in duplicate on five out of the 18 samples to check the reproducibility of the method. Results of the $\mathrm{P}-\mathrm{CaCl}_{2}$-extractions are reported as $\%$ of total $\mathrm{P}$ that has been dissolved, which was logical because of the fixed total $\mathrm{P}$ level in the suspensions. For $\mathrm{P}-\mathrm{CaCl}_{2}$ (initial $\mathrm{pH}$ ), difference between duplicates was $<0.7 \%$ of $\mathrm{P}$ total (absolute difference). For $\mathrm{P}-\mathrm{CaCl}_{2, \mathrm{pH} 5 \cdot 5}$ values, relative differences between duplicates was less than $15 \%$ (relative difference).

Table 2. Overview of the P pools and associated analytical methods used to assess P speciation in the solid organic fertilisers.

\begin{tabular}{|c|c|c|}
\hline Name & P-Pool & Analytical Method \\
\hline$P_{t}$ & Total P & P soluble after destruction with aqua regia \\
\hline$P_{t / k u o}$ & Total P & $\begin{array}{l}\text { P-PO } \mathrm{PO}_{4} \text { extracted with } 0.5 \mathrm{M} \mathrm{H}_{2} \mathrm{SO}_{4} \text { after oxidation at } \\
550{ }^{\circ} \mathrm{C}\end{array}$ \\
\hline$P_{\text {io }}$ & Total inorganic $\mathrm{P}$ & $\mathrm{P}_{-} \mathrm{PO}_{4}$ soluble in $0.5 \mathrm{M} \mathrm{H}_{2} \mathrm{SO}_{4}$ \\
\hline $\mathrm{P}_{\mathrm{o}}$ & Total organic $P$ & Difference $P_{t, k u o}$ and $P_{i o}$ \\
\hline $\mathrm{P}_{\mathrm{ox}}$ & $\begin{array}{l}\text { P associated with Fe- and Al-oxides, acid-soluble } \mathrm{P} \\
\text { salts and a part of the organic } \mathrm{P}\end{array}$ & $\begin{array}{l}\text { P extracted in acid ammonium-oxalate, measured as } \\
\text { total P (ICP-OES) }\end{array}$ \\
\hline $\mathrm{P}-\mathrm{CaCl}_{2}$ & Directly available P without $\mathrm{pH}$ adjustment & $\begin{array}{c}\mathrm{P} \text { extractable in } 10 \mathrm{mM} \mathrm{CaCl}_{2} \text { using fresh material and } \\
\text { at a predetermined total } \mathrm{P} \text { concentration of } 150 \mathrm{mg} / \mathrm{L} \\
\text { in the suspension }{ }^{\text {a }}\end{array}$ \\
\hline $\mathrm{P}-\mathrm{CaCl}_{2}(\mathrm{pH} 5 \cdot 5)$ & Easily soluble P at pH 5.5 & $\begin{array}{l}\text { As } \mathrm{P}-\mathrm{CaCl}_{2} \text { but after lowering the } \mathrm{pH} \text { of the } \\
\text { suspension to } 5.0 \text { (at equilibrium, average } \mathrm{pH} \text { was } 5.5 \text { ) }\end{array}$ \\
\hline
\end{tabular}

a The method differs from the standard $\mathrm{P}-\mathrm{CaCl}_{2}$-extraction approach for soils which uses a fixed soil to solution ratio of $0.1 \mathrm{~kg} / \mathrm{L}$. Here, a fixed total amount of $\mathrm{P} / \mathrm{L}$ of extractant was used to prevent artefacts due to the wide range of $\mathrm{P}$-contents in organic fertilisers.

\subsection{Data Analysis}

Statistical analyses were performed using IBM SPSS Statistics software (version 23). Simple or multiple linear regression analyses were carried out to evaluate the relationships between some of the variables across all treatments. The strength of the correlations was reported using the coefficients of determination $\left(\mathrm{R}^{2}\right)$. All tests were carried out at a significance level of $\alpha=0.05$.

\section{Results and Discussion}

\subsection{General Composition}

There is a large variation in the composition of the studied SOFs (Table 3) which was attributed to the differences in their feedstocks and processing treatments (Table 2). Dry weight varied considerably between the SFs of digestate (23 to 95\%) depending on the type of dewatering equipment used and whether a drying step was included on the plant. The OM content on DW basis was highest in the SFs of digestate ( $46 \%$ to $93 \%$ ), low to moderate in the composts (16-44\%), and lowest in the sieved soils (11-21\%). Among the SFs, AMP-SF and BP-SF showed the lowest OM contents on DW basis with $46 \%$ and $49 \%$, respectively. These low OM values, which were similar to those measured in the composts, coincide with the highest Fe contents (35 and $20 \mathrm{~g} / \mathrm{kg}$ DW, respectively), and this may point to the addition of iron salts during the process and/or the presence of significant amounts of mineral particles in the feedstock i.e., garden waste, crop residues or iron-rich sludges used in the anaerobic digester. The $\mathrm{pH}$ of the SFs of digestate and composts varied between 7.0 and 8.7, which fell within the normal range for such organic products [46-48], except for the SF with reduced P content (GZV-SF2) which had a slightly acidic pH of 
5.5 due to treatment with sulphuric acid. Alkaline $\mathrm{pH}$ in digestates and compost may induce precipitation of phosphates with $\mathrm{Ca}$ and $\mathrm{Mg}$ to form (poorly water-soluble) calcium phosphate and struvite compounds [49].

Table 3. Composition of the studied solid fractions (SF's) of digestate, composts (COMP) and sieved soils (soil) expressed on dry weight $(\mathrm{DW})^{\mathrm{a}, \mathrm{b}}$.

\begin{tabular}{|c|c|c|c|c|c|c|c|c|c|c|c|c|c|c|}
\hline \multirow{2}{*}{ Sample } & DW & OM & $\mathrm{pH}-\mathrm{CaCl}_{2}$ & $\mathbf{P}_{\mathrm{t}}$ & $\mathbf{N}_{\mathrm{t}}$ & $K_{t}$ & $\mathrm{Mg}_{\mathrm{t}}$ & $\mathrm{Ca}_{\mathrm{t}}$ & $S_{t}$ & $\mathrm{Fe}_{\mathrm{t}}$ & $\mathrm{Fe}_{\mathrm{ox}}$ & $A 1_{o x}$ & $\mathrm{Fe}_{\mathrm{ox}} / \mathrm{Fe}_{\mathrm{t}}$ & $P_{t} / O M$ \\
\hline & $\%$ & $\%$ of DW & - & \multicolumn{9}{|c|}{ g/kg DW } & - & $\mathrm{g} / \mathrm{kg}$ \\
\hline AMP-SF & 80 & 46 & 8.6 & 28 & 18 & 16 & 11 & 32 & 17 & 35 & 25.9 & 1.4 & 0.74 & 60 \\
\hline WNE-SF1 & 95 & 65 & 8.1 & 26 & 28 & 22 & 11 & 49 & 13 & 13 & 9.6 & 0.5 & 0.73 & 39 \\
\hline WNE-SF2 & 56 & 62 & 7.9 & 23 & 31 & 51 & 9.7 & 41 & 19 & 11 & 8.4 & 0.4 & 0.74 & 38 \\
\hline GZV-SF1 & 31 & 76 & 8.7 & 28 & 38 & 16 & 19 & 30 & 6.5 & 2.8 & 2.4 & 0.2 & 0.86 & 37 \\
\hline GZV-SF2 & 23 & 93 & 5.0 & 3.8 & 14 & $<1.0$ & 2.1 & 9.6 & 10 & 2.3 & 1.6 & $<0.05$ & 0.69 & 4.1 \\
\hline BNS-SF1 & 25 & 91 & 8.7 & 6.2 & 34 & 23 & 3.4 & 7.0 & 3.9 & 5.5 & 4.5 & $<0.05$ & 0.81 & 6.8 \\
\hline BNS-SF2 & 66 & 92 & 7.1 & 4.7 & 12 & 16 & 2.9 & 8.3 & 4.2 & 5.5 & 4.4 & $<0.05$ & 0.80 & 5.1 \\
\hline BP-SF & 33 & 49 & 8.4 & 5.1 & 26 & 14 & 4.8 & 64 & 9.8 & 20 & 15.2 & 0.3 & 0.76 & 10 \\
\hline DF-SF & 26 & 79 & 7.1 & 12 & 25 & 29 & 12 & 26 & 7.5 & 2.6 & 1.8 & 0.1 & 0.69 & 15 \\
\hline $\begin{array}{c}\text { VFG- } \\
\text { COMP1 }\end{array}$ & 69 & 41 & 7.8 & 3.4 & 16 & 13 & 4.8 & 35 & 2.9 & 11 & 2.0 & 0.3 & 0.18 & 8.2 \\
\hline $\begin{array}{c}\text { VFG- } \\
\text { COMP2 }\end{array}$ & 69 & 43 & 7.6 & 3.5 & 15 & 9.6 & 3.7 & 32 & 6.6 & 5.0 & 1.7 & 0.7 & 0.35 & 8.1 \\
\hline $\begin{array}{c}\text { VFG- } \\
\text { COMP3 }\end{array}$ & 60 & 35 & 8.0 & 2.6 & 14 & 9.1 & 3.6 & 23 & 2.1 & 7.3 & 2.4 & 0.6 & 0.33 & 7.5 \\
\hline $\begin{array}{c}\text { VFG- } \\
\text { COMP4 }\end{array}$ & 67 & 44 & 7.5 & 3.1 & 18 & 13 & 4.5 & 30 & 2.6 & 11 & 4.6 & 0.5 & 0.41 & 7.1 \\
\hline $\begin{array}{c}\text { GW- } \\
\text { COMP1 }\end{array}$ & 42 & 39 & 7.9 & 1.5 & 7.9 & 7.0 & 2.9 & 24 & 1.1 & 10 & 2.7 & 0.3 & 0.27 & 4.0 \\
\hline $\begin{array}{c}\text { GW- } \\
\text { COMP2 }\end{array}$ & 67 & 16 & 7.0 & 1.1 & 6.0 & 3.8 & 1.9 & 8.8 & 1.5 & 8.6 & 3.0 & 0.6 & 0.35 & 6.7 \\
\hline Soil1 & 70 & 21 & 6.9 & 1.3 & 7.0 & 4.6 & 1.7 & 12 & 1.1 & 6.3 & 2.5 & 0.7 & 0.39 & 6.2 \\
\hline Soil2 & 75 & 11 & 6.8 & 0.8 & 3.6 & 1.8 & 1.4 & 8.6 & 0.6 & 5.1 & 2.6 & 0.8 & 0.50 & 7.4 \\
\hline Soil3 & 66 & 18 & 6.7 & 0.8 & 3.9 & 1.7 & 1.1 & 5.8 & 0.5 & 4.5 & 2.3 & 0.9 & 0.52 & 4.3 \\
\hline
\end{tabular}

a DW: dry weight: OM: organic matter. SF: Solid fraction, AMP: Am-Power, GZV: Groot Zevert Vergisting, BNS: Benas, WNE: Waterleau New Energy, APF: Arjan Prinsen Farm, VFG-COMP: compost of vegetable, fruit and garden (VFG) waste, GW-COMP: compost of garden waste $(\mathrm{GW}) .{ }^{\mathrm{b}}$ Total amounts of $\mathrm{P}, \mathrm{Ca}, \mathrm{Mg}, \mathrm{K}, \mathrm{S}$ and Fe after destruction with aqua regia. Fe-ox and Al-ox determined after extraction with acid ammonium-oxalate/oxalic acid.

$\mathrm{P}_{\mathrm{t}}$ contents varied widely between and within the product types. The SFs of digestate contained between 3.8-28 g P/kg DW, with the lowest $P_{t}$ in the SF that underwent $P$ recovery (GZV-SF2) and the highest in the SF from GZV without P recovery (GZV-SF1). Differences in $\mathrm{P}_{\mathrm{t}}$ contents of the SFs were due to differences in digester feedstock, with rather low $P_{t}$ contents in SFs produced from digestate of energy crops (BNS-SF1\&2) and beet pulp (BP-SF) and high $\mathrm{P}_{\mathrm{t}}$ contents in SFs from biowaste (AMP-SF) or co-digested pig manure (WNE-SF1\&2 and GVZ-SF1). An exception was GZV-SF2 in which the $P_{t}$ content was reduced by nearly $90 \%$ after the post-treatment step in which the SF (GZVSF1) was leached with water and sulphuric acid at a $\mathrm{pH}$ of 5.0. This process, which is running at full scale at GZV, is referred to as the RePeat process and described in more detail elsewhere [39]. The VGF composts contained low $P_{t}$ contents ranging from 2.6 to $4.0 \mathrm{~g} \mathrm{P} / \mathrm{kg}$ DW while lower values were found in GW compost $(1.1-1.5 \mathrm{~g} / \mathrm{kg} \mathrm{DW})$ and the sieved soils $(0.8-1.3 \mathrm{~g} / \mathrm{kg}$ DW). However, the actual amount of $\mathrm{P}$ that will be made available to plants depends on the level of extractable or bioavailable P rather than on the total $P$ content. 
The $\mathrm{P}_{\mathrm{t}} / \mathrm{OM}$ ratio, which is a determinant for the amount of $\mathrm{P}$ added to the soil per unit of OM, varied widely and more so in the SFs of digestate $(4-60 \mathrm{~g} / \mathrm{kg})$ than in the composts $\left(4-8 \mathrm{~g} / \mathrm{kg}\right.$ ) and soils $(4-7 \mathrm{~g} / \mathrm{kg}$ ) (Table 3$)$. SOFs with high $\mathrm{P}_{\mathrm{t}} / \mathrm{OM}$ ratios should primarily be considered as $\mathrm{P}$ fertilisers whereas SOFs with low $\mathrm{P}_{\mathrm{t}} / \mathrm{OM}$ ratios can be considered primarily as organic soil improvers. There is no clear distinction between a $\mathrm{P}$ fertiliser and an organic soil improver, but in general, an SOF with a $\mathrm{P}_{\mathrm{t}} / \mathrm{OM}$ ratio of $10 \mathrm{~g} / \mathrm{kg}$ or lower can be considered as organic soil improvers because they enable a farmer to apply about $2500 \mathrm{~kg}$ of organic matter without exceeding the yearly average P uptake or arable crops (roughly $25 \mathrm{~kg} \mathrm{P} / \mathrm{ha}$ ) [50]. Using this criterion, composts can be considered as organic soil improvers fractions as well as those SFs that have low $\mathrm{P}_{\mathrm{t}} / \mathrm{OM}$ ratios such as GZV-SF2, in which $\mathrm{P}$ has been removed by means of acid, and the BNS-SF1\&2 which originate from digestate of energy crops. Sieved soils are also characterised by $\mathrm{P}_{\mathrm{t}} / \mathrm{OM}$ ratios below 10, however, sieved soil should be considered as soil rather than as organic soil improver because of its low OM content $(<21 \%$ of DW).

Similar to $\mathrm{P}_{\mathrm{t}}$, total concentrations of $\mathrm{N}, \mathrm{K}, \mathrm{Mg}, \mathrm{Ca}$ and $\mathrm{S}$ showed great variation in the SOFs (Table 3). Nitrogen content varied between 12 and $34 \mathrm{~g} / \mathrm{kg}$ DW in SFs of digestate and was influenced by the processing of the digestate. Thermal drying (AMP-SF), ammonia stripping (BNS-SF2) and leaching with acid (GZV-SF2) generally resulted in lower $\mathrm{N}$ contents as compared to SFs from digestate that had not undergone such a treatment to remove nitrogen from the solid fraction. Nitrogen contents of compost samples varied between 7 and $16 \mathrm{~g} / \mathrm{kg}$ which is somewhat lower as compared to the SFs. However, in terms of agronomic efficiency, the $\mathrm{N}$ mineralisation rate is the factor determining nitrogen availability from SOFs. N/P ratios in composts and SFs of digestate varied between 0.7 and $6.0 \mathrm{~kg} / \mathrm{kg}$. Assuming an $\mathrm{N}$ mineralisation coefficient of $10 \%$ for composts and $55 \%$ for SFs of digestate [47], the effective $\mathrm{N} / \mathrm{P}$ ratio is $<2 \mathrm{~kg} / \mathrm{kg}$, with the exception of the low-P product (GZV-SF2). Hence, the effective N/P ratio of the SOFs under investigation is low as compared to the $\mathrm{N} / \mathrm{P}$ crop requirements [51] and this further confirms that all tested products should primarily be regarded as $\mathrm{P}$ fertilisers or organic soil improvers rather than as $\mathrm{N}$ fertilisers.

\subsection{Total and Reactive Fe}

Total iron $\left(\mathrm{Fe}_{\mathrm{t}}\right)$ in the SOFs varied between 2.6 and $35.2 \mathrm{~g} / \mathrm{kg}$ DW (Table 3). Among the SFs of digestate, $\mathrm{Fe}_{\mathrm{t}}$ was highest in fertilisers produced by companies that add Fe salts or treat Fe-rich feedstocks such as flotation sludges from the food industry (AMP, BP and WNE). When no Fe was added, $\mathrm{Fe}_{\mathrm{t}}$ in SFs was below $5.5 \mathrm{~g} / \mathrm{kg}$ DW. In the VFG-composts, $\mathrm{Fe}_{\mathrm{t}}$ varied between 5.0 and $11.4 \mathrm{~g} / \mathrm{kg} \mathrm{DW}$ and was similar to $\mathrm{Fe}_{\mathrm{t}}$ in $\mathrm{GW}$-compost and only slightly higher as compared to $\mathrm{Fe}_{\mathrm{t}}$ in sieved soils (4.5-6.3 g/kg DW). There was no difference in $\mathrm{Fe}_{\mathrm{t}}$ content between composts from treatment plants where VFG-waste was anaerobically digested with Fe-salts (VFG-COMP3\&4) and composts that did not receive Fe-salts during processing (VFG-COMP1\&2). Composts consist of more than 50\% of mineral particles, mostly soil particles, and differences in $\mathrm{Fe}_{\mathrm{t}}$ content between composts are most likely due to differences in the mineralogy of the mineral soil fraction.

The $\mathrm{Fe}_{\mathrm{ox}}$ content is regarded as an indicator for the reactive Fe-oxides in the SOFs. Though $\mathrm{Fe}_{\mathrm{ox}}$ correlated with $\mathrm{Fe}_{\mathrm{t}}\left(\mathrm{R}^{2}: 0.89, p<0.01\right)$, there are distinct differences in the $\mathrm{Fe}_{\mathrm{ox}} / \mathrm{Fe}_{\mathrm{t}}$ ratio between product groups. The average $\mathrm{Fe}_{\mathrm{ox}} / \mathrm{Fe}_{\mathrm{t}}$ ratio was high in $\mathrm{SFs}$ of digestate $(0.76 \pm 0.06)$ as compared to the composts $(0.31 \pm 0.08)$ and sieved soil $(0.46 \pm 0.07)$ which points to differences in the origin of Fe between these product groups. Low $\mathrm{Fe}_{\mathrm{ox}} / \mathrm{Fe}_{\mathrm{t}}$ ratios in composts and sieved soils point to the presence of Fe in crystalline minerals such as goethite or clay minerals that do not dissolve in the acid oxalate extraction medium. On the other hand, $\mathrm{Fe}_{\mathrm{ox}} / \mathrm{Fe}_{\mathrm{t}}$ is $>0.70$ in all SFs of digestate regardless of whether Fe salts were added during processing. This points to Fe being dominantly present in the reactive form due to its association with organic matter or presence of extractable minerals including ferrihydrite $\left(\mathrm{Fe}_{2} \mathrm{O}_{3} \cdot 0.5 \mathrm{H}_{2} \mathrm{O}\right)$, iron sulfide $(\mathrm{Fe}(\mathrm{II}) \mathrm{S})$, strengite $\left(\mathrm{Fe}(\mathrm{III}) \mathrm{PO}_{4} \cdot 2 \mathrm{H}_{2} \mathrm{O}\right)$ 
and vivianite $\left(\mathrm{Fe}(\mathrm{II})\left(\mathrm{PO}_{4}\right)_{2} \cdot 8 \mathrm{H}_{2} \mathrm{O}\right)$ [18]. This also underscores that $\mathrm{Fe}_{\mathrm{ox}}$ rather than $\mathrm{Fe}_{\mathrm{t}}$ should be used as an indicator for determining the $\mathrm{P}$ binding capacity of SOFs.

$\mathrm{Al}_{\mathrm{ox}}$ contents were low compared to $\mathrm{Fe}_{\mathrm{ox}}$ contents and not distinctive for sieved soils, compost or SFs of digestate (Table 3). $\mathrm{Al}_{\mathrm{ox}}$ contents were below the detection limit $(0.05 \mathrm{~g} / \mathrm{kg})$ in SFs of digestate from AD plants which were dominantly fed with animal manure (GZV, APF) or energy crops (BNS) and higher in SOFs that include garden waste or crop residue that may contain mineral soil particles such as beet tips and potato peels. $\mathrm{Al}_{\mathrm{Ox}}$ decreased with increasing OM content $\left(\mathrm{R}^{2}=0.510, p<0.01\right)$ regardless of product type. We, therefore, argue that $\mathrm{Al}_{\mathrm{ox}}$ mostly originates from the mineral fraction associated with the feedstock which explains the negative correlation between $\mathrm{Al}_{\mathrm{ox}}$ and $\mathrm{OM}$. Such a correlation with OM was not found for $\mathrm{Fe}_{\mathrm{ox}}$ and $\mathrm{Fe}_{\mathrm{t}}$ since Fe can enter SOFs either as a constituent of soil particles, through the addition of Fe salts or from the treatment of Fe-rich sludges.

Overall, this points to a dominant role of mineral soil particles in determining levels of $\mathrm{Fe}$ and $\mathrm{Al}$ in composts and sieved soils whereas Fe levels in SFs of digestate are related to the use of Fe-salts or treatment of wastewater sludges containing precipitated Fe-salts.

\subsection{Inorganic and Organic $P$}

Inorganic $\mathrm{P}$, defined as $\mathrm{P}$ extractable in $0.5 \mathrm{M} \mathrm{H}_{2} \mathrm{SO}_{4}$, was the dominant fraction in all SOFs representing 65-101\% of $\mathrm{P}_{\mathrm{t}}$. Hence, only a small fraction of $\mathrm{P}_{\mathrm{t}}$ was present in organic form $(<24 \%)$ and this was not distinctive for the different product types. Similarly, other authors found that only a small fraction of $\mathrm{P}_{\mathrm{t}}$ was present as organic $\mathrm{P}$ in composts and digestates from manure and biowaste [10,52].

The total $\mathrm{P}$ content after dry combustion and extraction $\left(\mathrm{P}_{\mathrm{t}, \mathrm{kuo}}\right)$ was on average $10 \%$ lower as compared to the $\mathrm{P}_{\mathrm{t}}$ content determined by wet digestion. Other researchers found that dry combustion followed by extraction of $\mathrm{P}$ in $0.5 \mathrm{M} \mathrm{H}_{2} \mathrm{SO}_{4}$ slightly underestimated $\mathrm{P}_{\mathrm{t}}$ which was attributed to incomplete oxidation of $\mathrm{OM}$, volatilization of $\mathrm{P}$ and formation of insoluble $\mathrm{P}$ crystals during dry combustion at $550{ }^{\circ} \mathrm{C}[53,54]$. It is also known that artefacts may occur in the determination of the inorganic $\mathrm{P}$ fraction including hydrolysis of organic $\mathrm{P}$ during the extraction of the inorganic $\mathrm{P}$ which, in turn, also affects the calculated organic P content [54].

$\mathrm{P}_{\mathrm{ox}}$ contents, extracted with acid ammonium-oxalate, were similar to amounts of inorganic P extracted with $0.5 \mathrm{M} \mathrm{H}_{2} \mathrm{SO}_{4}\left(\mathrm{R}^{2}\right.$ : 0.99, $\left.\mathrm{P}<0.01\right)$ indicating that despite the differences in extraction medium, both analytical methods likely extracted the same P pool from the SOFs. $\mathrm{P}_{\text {ox }}$ made up $61-87 \%$ of $\mathrm{P}_{\mathrm{t}}$. In soil science, $\mathrm{P}_{\mathrm{ox}}$ is regarded as the amount of $\mathrm{P}$ adsorbed to amorphous Fe- and Al-oxides and, in combination with the $\mathrm{Fe}_{\mathrm{ox}}$ and $\mathrm{Al}_{\mathrm{ox}}$ content, used to calculate the degree of P saturation of the oxides in the soil [55]. However, when applied to SOFs, $\mathrm{P}_{\text {ox }}$ may seriously overestimate the amount of $\mathrm{P}$ adsorbed to Fe- and Al-oxides because the acid oxalate extraction solution also dissolves commonly present phosphate precipitates such as struvite and brushite $\left(\mathrm{CaHPO}_{4} \cdot 2 \mathrm{H}_{2} \mathrm{O}\right)[56,57]$. Hence, a more sophisticated calculation is needed to derive the amount of $\mathrm{P}$ bound to Fe-oxides in SOFs.

\subsection{P Associated with Fe/Al-Oxides}

The degree of P saturation (DPS) of the Fe/Al-oxides in SOF's can be calculated with Equation (1);

$$
\operatorname{DPS}(-)=\frac{\mathrm{P}_{\mathrm{ox}}}{0.5 \times\left(\mathrm{Fe}_{\mathrm{ox}}+\mathrm{Al}_{\mathrm{ox}}\right)}
$$

in which $\mathrm{P}_{\mathrm{ox}}, \mathrm{Fe}_{\mathrm{ox}}$ and $\mathrm{Al}_{\mathrm{ox}}$ are expressed in $\mathrm{mmol} / \mathrm{kg}$. The factor 0.5 refers to the maximum amount of $\mathrm{P}$ that can be bound to Fe/Al-oxides and has been derived for noncalcareous sandy soils [58]. It may, however, underestimate the $\mathrm{P}$ binding capacity in case Fe and $\mathrm{P}$ have precipitated to form vivianite $\left(\mathrm{Fe}_{3}\left(\mathrm{PO}_{4}\right)_{2} \cdot 8 \mathrm{H}_{2} \mathrm{O}\right)$ which has a molar $\mathrm{P} / \mathrm{Fe}$ ratio of $2: 3$ and forms under anaerobic conditions [18].

The DPS approach was originally developed to predict P leaching in soils [59] but was also successfully applied to predict P leaching from SOFs [12,21]. Elliot et al. [12] applied 
this approach to biosolids with high levels of $\mathrm{Fe}_{\mathrm{ox}}$ as compared to $\mathrm{P}_{\mathrm{ox}}$ and showed that a DPS $>1$ corresponded to an increased risk for $P$ leaching from the biosolids. In our study, DPS values of SFs of digestate and VFG compost were all above one except for the SF-BP where iron was added during processing (Table 4). Sieved soil and GW compost had DPS values below one meaning that $\mathrm{Fe} / \mathrm{Al}$-oxides are not fully saturated with $\mathrm{P}$.

Table 4. Percentage distribution of total $\mathrm{P}\left(\mathrm{P}_{\mathrm{t}}\right)$ over the distinguished $\mathrm{P}$ species as well as the degree of $\mathrm{P}$ saturation (DPS) of the $\mathrm{Fe} / \mathrm{Al}$ oxides ${ }^{\mathrm{a}}$.

\begin{tabular}{|c|c|c|c|c|c|c|c|}
\hline \multirow[t]{2}{*}{ Sample ${ }^{b}$} & Inorganic $\mathbf{P}$ & Organic $\mathbf{P}$ & $\mathbf{P}_{\text {ox }}$ & $\mathrm{P}-\mathrm{CaCl}_{2}$ & $\begin{array}{c}\mathrm{P}- \\
\mathrm{CaCl}_{2, \mathrm{pH} 5 \cdot 5}\end{array}$ & DPS & $\mathbf{P}_{\mathrm{Fe}}$ \\
\hline & & & $\%$ of $P_{t}$ & & & $(-)$ & $\%$ of $P_{t}$ \\
\hline AMP-SF & 97 & 0.0 & 87 & 1.2 & 21 & 3.0 & 29 \\
\hline WNE-SF1 & 90 & 4.6 & 79 & 1.5 & 37 & 6.9 & 12 \\
\hline WNE-SF2 & 86 & 1.7 & 84 & 2.3 & 33 & 7.6 & 11 \\
\hline GZV-SF1 & 75 & 0.6 & 74 & 2.1 & 87 & 27 & 3 \\
\hline GZV-SF2 & 75 & 5.9 & 74 & 40 & 40 & 6.6 & 11 \\
\hline BNS-SF1 & 89 & 1.5 & 84 & 2.0 & 45 & 4.2 & 20 \\
\hline BNS-SF2 & 65 & 23 & 74 & 2.9 & 26 & 2.9 & 26 \\
\hline BP-SF & 65 & 18 & 61 & 1.2 & 14 & 0.7 & 87 \\
\hline DF-SF & 75 & 5.6 & 80 & 8.3 & 45 & 17 & 5 \\
\hline VFG-COMP1 & 76 & 8.5 & 62 & 0.4 & 18 & 2.8 & 22 \\
\hline VFG-COMP2 & 86 & 9.5 & 74 & 4.9 & 22 & 3.0 & 25 \\
\hline VFG-COMP3 & 89 & 8.1 & 71 & 0.6 & 22 & 1.8 & 39 \\
\hline VFG-COMP4 & 83 & 20 & 71 & 0.9 & 15 & 1.4 & 50 \\
\hline GW-COMP1 & 69 & 21 & 55 & 0.5 & 13 & 0.9 & 55 \\
\hline GW-COMP2 & 70 & 22 & 61 & 0.3 & 2 & 0.6 & 61 \\
\hline Soil1 & 76 & 13 & 64 & 0.4 & 6 & 0.7 & 64 \\
\hline Soil2 & 63 & 18 & 64 & 0.1 & 1 & 0.4 & 64 \\
\hline Soil3 & 65 & 22 & 64 & 0.2 & 1 & 0.4 & 64 \\
\hline
\end{tabular}

${ }^{a} \mathrm{P}_{\mathrm{t}}$ : total P. Inorganic P: determined after extraction with $0.5 \mathrm{M} \mathrm{H}_{2} \mathrm{SO}_{4}$. Organic P: difference between $\mathrm{P}_{\mathrm{t}, \mathrm{kuo}}(\mathrm{P}$ extracted after dry combustion followed by extracting with $0.5 \mathrm{M} \mathrm{H}_{2} \mathrm{SO}_{4}$ ) and inorganic P. $\mathrm{P}_{\mathrm{ox}}$ : P extracted in acid ammonium oxalate. P-CaCl $2: \mathrm{P}^{-\mathrm{PO}_{4}}$ extracted with $10 \mathrm{mM} \mathrm{CaCl}_{2}$ at a fixed total $\mathrm{P}$ concentration in the suspension of $150 \mathrm{mg} \mathrm{P} / \mathrm{L}$. P-CaCl $2, \mathrm{pH} 5 \cdot 5$ : as P-CaCl 2 but at a pH of the suspension of 5.5. DPS: degree of $\mathrm{P}$ saturation (Equation (1)). $\mathrm{P}_{\mathrm{Fe}}$ : $\mathrm{P}$ bound to $\mathrm{Fe} / \mathrm{Al}$ oxides based on the $\mathrm{P}$ binding capacity of the organic fertiliser, calculated using Equations (2) and (3). ${ }^{\text {b }}$ SF: solid fraction, AMP: Am-Power, GZV: Groot Zevert Vergisting, BNS: Benas, WNE: Waterleau New Energy, DF: dairy farm, VFG-COMP: compost of vegetable, fruit and garden (VFG) waste, GW-COMP: compost of garden waste (GW)

The amount of $\mathrm{P}$ bound to Fe/Al-oxides can be calculated using the DPS to differentiate between saturated and nonsaturated conditions. If the DPS is above one, and hence the Fe/Al-oxides are saturated, the amount of $\mathrm{P}$ bound to $\mathrm{Fe} / \mathrm{Al}$-oxides is equal to the $\mathrm{P}$ binding capacity (PBC) and can be calculated with Equation (2);

$$
\mathrm{P}_{\mathrm{Fe}}\left(\frac{\mathrm{g}}{\mathrm{kg}}\right)=\mathrm{PBC}=0.5 *\left(\mathrm{Fe}_{\mathrm{ox}}+\mathrm{Al}_{\mathrm{ox}}\right) \times 31 \times 1000(\text { if DPS }>1)
$$

in which $\mathrm{P}_{\mathrm{Fe}}$ is the amount of $\mathrm{P}$ bound to $\mathrm{Fe} / \mathrm{Al}$-oxides and expressed in $\mathrm{g} / \mathrm{kg} \mathrm{DW}$ whereas $\mathrm{Fe}_{\mathrm{ox}}$ and $\mathrm{Al}_{\mathrm{ox}}$ are in $\mathrm{mmol} / \mathrm{kg} \mathrm{DW}$. The criteria of DPS $>1$ is true for all SFs of digestates and VFG-composts. 
If the DPS is below one, meaning that $\mathrm{Fe} / \mathrm{Al}$-oxides are not fully saturated with $\mathrm{P}, \mathrm{P}_{\mathrm{Fe}}$ is assumed to equal $P_{\text {ox }}$ and Equation (3) is valid;

$$
\mathrm{P}_{\mathrm{Fe}}\left(\frac{\mathrm{g}}{\mathrm{kg}}\right)=\mathrm{P}_{\mathrm{ox}} \times 31 \times 1000 \text { (if DPS }<1 \text { ) }
$$

Table 4 gives $\mathrm{P}_{\mathrm{Fe}}$ expressed as a percentage of $\mathrm{P}_{\mathrm{t}}$. In the $\mathrm{SFs}$, between 3 to $29 \%$ of $\mathrm{P}_{\mathrm{t}}$ is bound to $\mathrm{Fe} / \mathrm{Al}$-oxides except for SF-BP in which $87 \%$ of $\mathrm{P}_{\mathrm{t}}$ was bound to $\mathrm{Fe} / \mathrm{Al}$-oxides. In GW composts and sieved soil, the majority of $\mathrm{P}_{t}$ is bound to Fe/Al-oxides (22-64\% of $\mathrm{P}_{t}$ ) whereas the VFG composts are in between SFs of digestate and GW composts (Table 4).

\subsection{Easily Available P}

The determination of $\mathrm{P}-\mathrm{CaCl}_{2}$ is relevant when assessing $\mathrm{P}$ release and availability in SOFs $[33,34]$ or soils $[31,60]$. Easily available $P$ was determined after extraction of fresh SOF with $10 \mathrm{mM} \mathrm{CaCl}_{2}$ using a fixed $\mathrm{P}_{\mathrm{t}}$ concentration of $150 \mathrm{mg} / \mathrm{L}$ in the suspension. Fresh samples were used since it is known that oven drying of manure and soil increases levels of easily soluble $P$ in manure [61] and soil samples [62].

Without $\mathrm{pH}$ adjustment, $\mathrm{P}$ extractable in $\mathrm{CaCl}_{2}$ was low and corresponded to $0-8 \%$ of $\mathrm{P}_{\mathrm{t}}$ except for GZV-SF2 in which $40 \%$ of $\mathrm{P}_{\mathrm{t}}$ was extractable in $\mathrm{CaCl}_{2}$. The latter SF had a $\mathrm{pH}$ of 5.0 due to the treatment it had undergone to remove P. In the other SFs and composts, $\mathrm{pH}$ values ranged between 7.0 and 8.6 implying that $\mathrm{P}-\mathrm{CaCl}_{2}$ is, in fact, controlled by the equilibrium product of phosphate precipitates such as struvite and brushite (Table S1). It was, therefore, concluded that $\mathrm{P}-\mathrm{CaCl}_{2}$ is unsuitable as an indicator for $\mathrm{P}$ availability in the studied SOFs due to the predominant influence of the SOF's $\mathrm{pH}$. This leads to an underestimation of available $\mathrm{P}$ when the $\mathrm{pH}$ of the $\mathrm{SOF}$ is high compared to the $\mathrm{pH}$ of the soil to which the SOF is added.

Lowering the $\mathrm{pH}$ of the $\mathrm{CaCl}_{2}$ suspensions led to, on average, a sevenfold increase in the average $\mathrm{P}$ concentration in the $\mathrm{CaCl}_{2}$ extracts. The $\mathrm{pH}$-values of the suspensions were initially lowered to 5.0, however, the $\mathrm{pH}$ slowly increased during the 30-min shaking period leading to an average $\mathrm{pH}$-value of $5.7 \pm 0.15$ (Table S2) upon sampling and indicating that controlling and maintaining $\mathrm{pH}$-values is difficult and laborious. The fraction of $\mathrm{P}-\mathrm{CaCl}_{2, \mathrm{pH} 5.5}$ extracted in the acidified $\mathrm{CaCl}_{2}$ extracts was distinguishable for the different product types. In SFs of digestate, $14-87 \%$ of $\mathrm{P}_{\mathrm{t}}$ was extracted at $\mathrm{pH} 5.5$ which was considerably higher as compared to the fraction extracted from composts (13-22\%) and sieved soils (1-6\%) (Table 4). At the lowered $\mathrm{pH}$, three mechanisms were predominant. Firstly, precipitated phosphates which are insoluble at the $\mathrm{pH}$ of the SOFs (mean $\mathrm{pH}$ $\approx 7.8$ ), are released into solution. This was evidenced by the concomitant increase in concentrations of $\mathrm{PO}_{4}{ }^{3-}, \mathrm{Mg}^{2+}$ and $\mathrm{NH}_{4}{ }^{+}$in ratios of 0.8 and $0.7 \mathrm{~mol}$ per mol of $\mathrm{PO}_{4}{ }^{3-}$, respectively (Figure 1). In addition to struvite, calcium phosphate minerals such as brushite may have been dissolved as well, but the change in Ca could not be determined due to the $10 \mathrm{mM} \mathrm{CaCl}_{2}$ background provided by the extracting solution. The second mechanism is the increased adsorption of $\mathrm{P}$ to reactive surfaces of Fe/Al-oxides at slightly acidic $\mathrm{pH}$ values $[63,64]$ and consequently, the saturation of $\mathrm{Fe} / \mathrm{Al}$-oxide binding sites with phosphate ions. Using an even lower $\mathrm{pH}$ value, though, e.g., a $\mathrm{pH}$ value $<4.0$, would lead to the dissolution of Fe-oxides and hence the release of associated P [63] and result in an overestimation of $\mathrm{P}$ release upon addition of the SOFs to non-calcareous agricultural soils. As such, the extraction at pH 5.5 targeted only the easily available P fraction that would also be released upon addition of the SOF to a non-calcareous agricultural soil which typically has a pH value of 5.0 to 6.0. Lastly, acidification of the $\mathrm{CaCl}_{2}$ suspensions caused a small increase in concentrations of organic $\mathrm{P}$ in the $\mathrm{CaCl}_{2}$ extracts. On average, $18 \%$ of $\mathrm{CaCl}_{2, \mathrm{pH} 5.5}$ was present in organic form (Table S2) and the organic $\mathrm{P}$ concentration increased upon acidification of the $\mathrm{CaCl}_{2}$ suspension. This is explained by the dissolution and release of acid-labile organic P into solution [65]. 


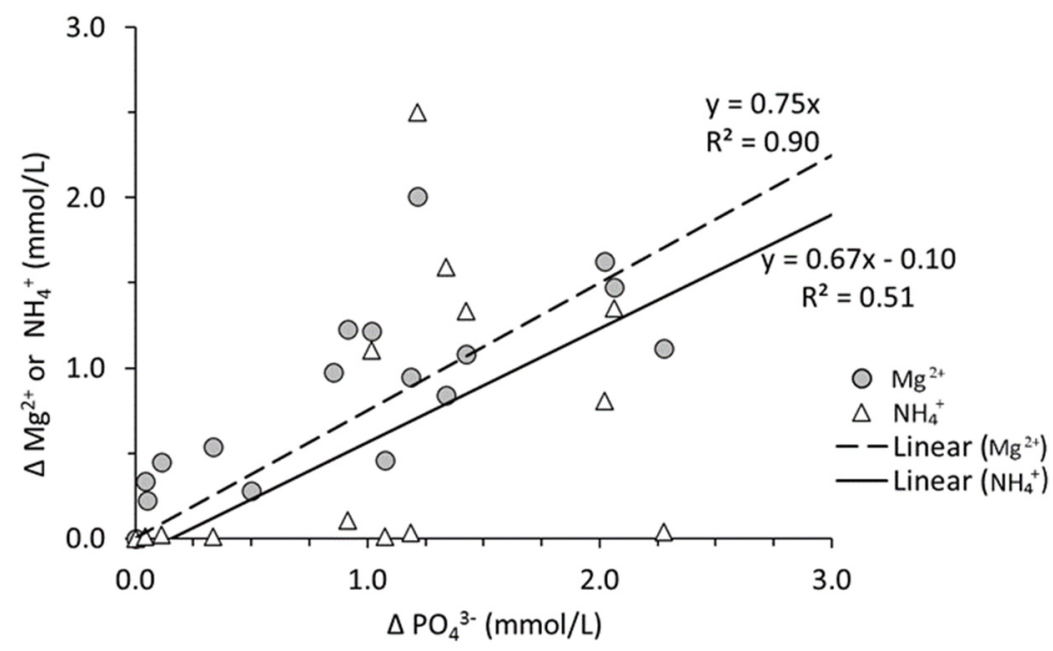

Figure 1. Increase in the molar concentration of $\mathrm{Mg}$ or $\mathrm{NH}_{4}$ (y-axis) plotted against the change in $\mathrm{PO}_{4}$ (x-axis) upon lowering the $\mathrm{pH}$ of the $\mathrm{CaCl}_{2}$ suspensions towards $\mathrm{pH} 5.0$ as compared to the initial $\mathrm{pH}$ of the $\mathrm{CaCl}_{2}$ suspensions. Lines are linear regression lines.

Figure $2 \mathrm{~A}$ shows the relationship between $\mathrm{P}-\mathrm{CaCl}_{2, \mathrm{pH} 5.5}$ and $\mathrm{P}_{\mathrm{Fe}}$, which are both expressed as $\%$ of $\mathrm{P}_{\mathrm{t}}$, and shows a strong negative correlation between the two parameters $\left(\mathrm{R}^{2}: 0.70, p<0.01\right)$. In SOFs where $50 \%$ or more of $\mathrm{P}_{\mathrm{t}}$ is bound to Fe/Al-oxides, less than $20 \%$ of $\mathrm{P}_{\mathrm{t}}$ is extractable in $\mathrm{CaCl}_{2}$ at $\mathrm{pH} 5.5$ which can be explained by the fact that $\mathrm{P}$ bound to $\mathrm{Fe} / \mathrm{Al}$-oxides does not dissolve in the $\mathrm{CaCl}_{2}$ at $\mathrm{pH}$ 5.5. The relationship between $\mathrm{P}-\mathrm{CaCl}_{2}(\mathrm{pH} 5 \cdot 5)$ and $\mathrm{P}_{\mathrm{Fe}}$ shows that $\mathrm{P}_{\mathrm{ox}}, \mathrm{Fe}_{\mathrm{ox}}$, and $\mathrm{Al}_{\mathrm{ox}}$ concentrations are useful measures for predicting the $\mathrm{P}$ fertilising potential of SOFs in slightly acidic soils.
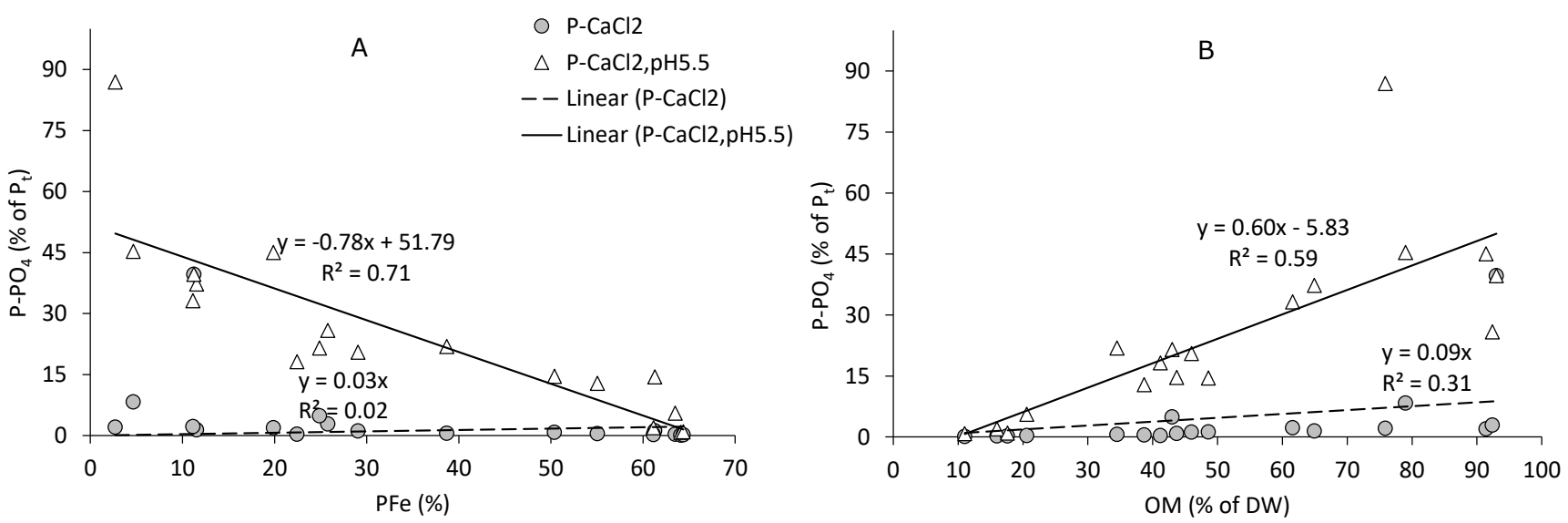

Figure 2. The relationships between $\mathrm{P}_{-} \mathrm{PO}_{4}(\%$ of $\mathrm{Pt}$ ) measured in $10 \mathrm{mM} \mathrm{CaCl}$ extracts (at initial $\mathrm{pH}$ and after acidification to $\mathrm{pH} 5.5)$ and $(\mathrm{A})$ the percentage of $\mathrm{P}$ bound to $\mathrm{Fe} / \mathrm{Al}$-oxides $\left(\mathrm{P}_{\mathrm{Fe}}\right)(\mathbf{B})$ organic matter content $(\% \mathrm{DW})$ in the organic fertilisers.

Multiple linear regression revealed that the OM content may also be a quick and simple indicator for available $P$ in SOFs as a significant and positive relationship $\left(R^{2}=0.59\right.$, $p<0.01$ ) was found between $\mathrm{P}-\mathrm{CaCl}_{2}(\mathrm{pH} 5 \cdot 5)$ and $\mathrm{OM}$ content (Figure 2B). In other words, $\mathrm{SOFs}$ with high $\mathrm{OM}$ content released more $\mathrm{P}-\mathrm{CaCl}_{2}$ under acidified conditions. However, there is no causal relation between the two parameters since the correlation is an effect of the positive correlation between OM content and $\mathrm{P}_{\mathrm{Fe}}\left(\mathrm{R}^{2}: 0.78, p<0.01\right)$. As a consequence, the reliability of $\mathrm{OM}$ as an indicator for the easily available $\mathrm{P}$ fraction may be limited when this relation is applied to other SOFs because (i) the relation was derived on a limited number of samples and (ii) it can be expected that the reliability of $\mathrm{OM}$ as an indicator 
decreases in samples in which the iron content is strongly influenced by the dosage of iron salts during the processing process.

\subsection{Speciation of $P$ in SOFs and Implications for Their Use in Agriculture}

Based on the analytical P pools (Table 4), $\mathrm{P}_{\mathrm{t}}$ in the SOFs was distributed over five distinct $\mathrm{P}$ species as visualised in Figure 3. Easily available $\mathrm{P}$ is defined as the fraction extractable in $\mathrm{P}_{-} \mathrm{CaCl}_{2}$ at $\mathrm{pH}$ 5.5. Iron-bound $\mathrm{P}$ was calculated using Equations (1)-(3). Crystalline $\mathrm{P}$ is defined as the difference between $\mathrm{P}_{\mathrm{ox}}$ minus $\mathrm{P}_{\mathrm{Fe}}$ and $\mathrm{P}-\mathrm{CaCl}_{2, \mathrm{pH} \cdot 5}$. Organic $\mathrm{P}$ is determined with the $\mathrm{P}_{\text {kuo }}$ method. Residual $\mathrm{P}$ is defined as the difference between $P_{t}$ determined after wet digestion and $P_{t, k u o}$ determined after dry combustion and may partly exist due to artefacts in the $\mathrm{P}_{\mathrm{t}, \mathrm{kuo}}$ method. Hence, the nature and speciation of $\mathrm{P}$ in the residual fraction are unknown.

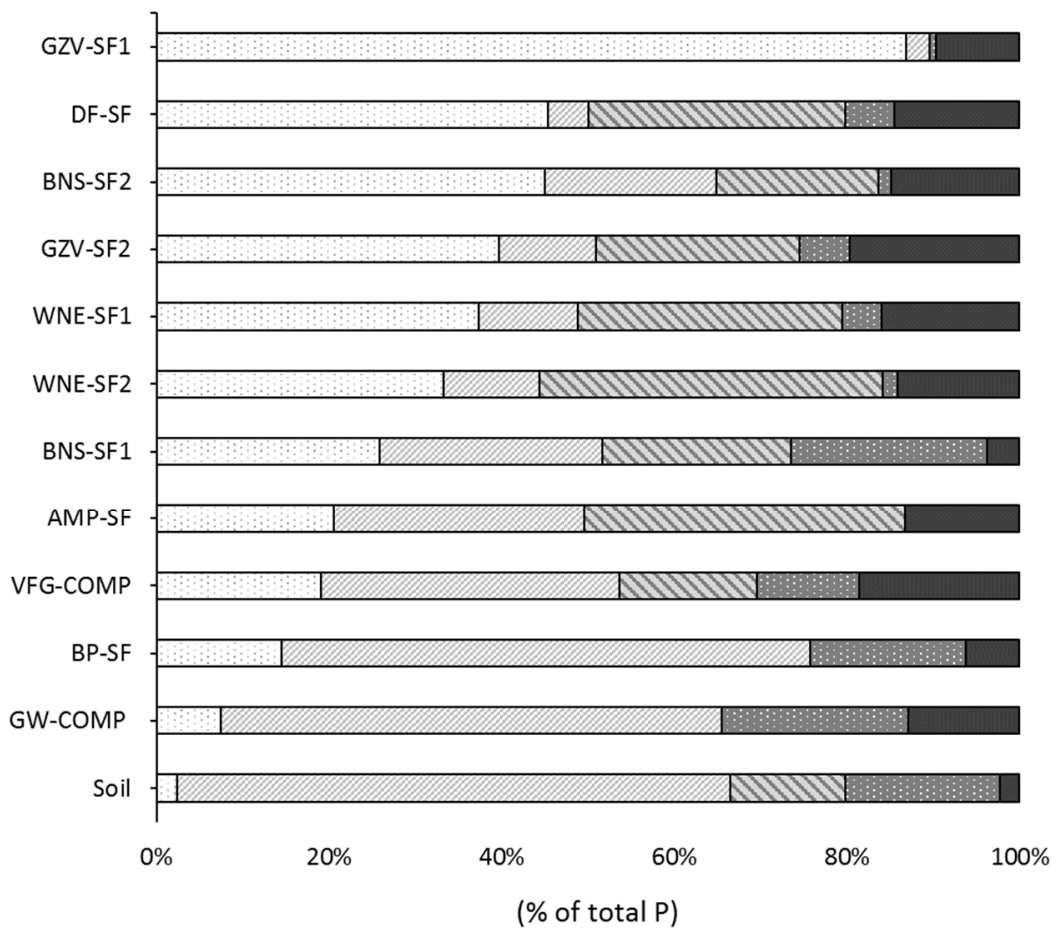

$\square$ Easily available $P \quad \square$ Fe/Al-oxides $P \quad \square$ Crystalline $P \quad \square$ Organic $P \quad \square$ Residual P

Figure 3. Distribution of phosphorus (P) species (\% of total $\mathrm{P}$ ) in solid fractions (SF) of digestate from different treatment plants, and average $\mathrm{P}$ distribution for composted vegetable, fruit and garden waste (VFG-COMP, n:4), composted green waste (GW-COMP, n:2) and sieved soil (Soil, n:3). The organic fertilisers are put in order of increasing percentage of easily available $P$.

The distribution of $\mathrm{P}_{\mathrm{t}}$ between the $\mathrm{P}$ species is shown in Figure 3, in which the SOFs are arranged in order of increasing fraction of easily available $\mathrm{P}$. The SF of digestate from GZV (GZV-SF1) has by far the highest fraction of easily available P ( $87 \%$ of $\mathrm{P}_{\mathrm{t}}$ ) and a negligible amount of $\mathrm{P}$ bound to $\mathrm{Fe} / \mathrm{Al}$ oxides because the use of Fe salts and Fe-rich substrates is avoided at this treatment plant. As a result, GZV-SF1 is the preferred fertiliser if the SOF is supposed to act primarily as a P fertiliser. In the other SFs of digestate, the percentage of easily available $\mathrm{P}$ was lower and this could only partly be explained by the use of Fe-rich feedstock or Fe-salts and hence binding of $\mathrm{P}$ to Fe-oxides. The other reason for the low availability of $\mathrm{P}$ in other SFs is the larger fraction of crystalline $\mathrm{P}$ but it is unknown what causes these differences in the fraction of crystalline P between SFs. Drying of the SFs of digestates may have led to an increase in the fraction of crystalline $P$ in SFs of Waterleau New Energy and AmPower. Crystalline P consists of poorly soluble P precipitates that were insoluble in $\mathrm{CaCl}_{2}$ at $\mathrm{pH} 5.5$ but dissolved in acid oxalate. Apatite 
and struvite are examples of crystalline $\mathrm{P}$ precipitates. Struvite is known to dissolve at $\mathrm{pH} 5.5$ but its dissolution rate is related to the size of the particle and hence, dissolution of struvite in $\mathrm{CaCl}_{2, \mathrm{pH} 5.5}$ may not have been complete during the 30-min shaking period. In acidic soils, the crystalline $P$ fraction is likely slowly released over time whereas this fraction may remain mostly unavailable for plant uptake when applied to calcareous soils in which dissolution rates of $P$ precipitates are even lower [17].

In the SF of beet pulp digestate (BP-SF), most of the $\mathrm{P}$ was bound to Fe/Al-oxides. At this plant, Fe sludge was added as an iron source. That sludge is a side product from the purification of anaerobic groundwater for the production of drinking water and consists of fine colloidal Fe-hydroxides. Though Fe is added to sorb $\mathrm{S}^{2-}$ [66], the addition of Fe also exerts a large negative effect on $P$ availability which can be explained by two factors. First, the binding of $\mathrm{P}$ to Fe may result in overdosage of Fe as compared to the amount of Fe needed to bind $\mathrm{H}_{2} \mathrm{~S}$. Secondly, upon contact with oxygen, sulphides oxidize to form sulphuric acid and Fe(III)-hydroxides, on which P is sorbed. It is likely that this biologically mediated process occurs during storage of the SFs. Iron salts or Fe sludge were also used in AmPower and Waterleau New Energy, yet the percentage of $\mathrm{P}_{\mathrm{Fe}}$ in AMP-SF and WNESF1\&2 was small (11-29\% of $\mathrm{P}_{\mathrm{t}}$ ) compared to $\mathrm{P}_{\mathrm{Fe}}$ in the SF from the beet pulp processing company $\left(61 \%\right.$ of $\left.\mathrm{P}_{\mathrm{t}}\right)$ which is due to the higher $\mathrm{P}_{\mathrm{t}}$ value and hence lower Fe $/ \mathrm{P}_{\mathrm{t}}$ ratio in the SFs of AmPower and Waterleau New Energy. Nevertheless, avoiding the use of Fe in the processing of digestate could be a step forward in improving the fertiliser value of SOFs. An alternative for removing $\mathrm{H}_{2} \mathrm{~S}$ from biogas is the use of chemical or biological scrubbers. Removal of $\mathrm{P}$ and enhanced solid-liquid separation can also be fulfilled by adding $\mathrm{Mg}$ salts $\left(\mathrm{MgCl}_{2}, \mathrm{MgO}\right)$ forming struvite upon reaction with $\mathrm{PO}_{4}{ }^{3-}$ which is available for plant uptake. $\mathrm{GZV}$ is nowadays using $\mathrm{MgCl}_{2}$ as an alternative for Fe salts, despite the higher costs, because they aim to produce a SF that is suitable as a $\mathrm{P}$ fertiliser.

In GW composts and sieved soil, P bound to Fe/Al-oxides was the dominant P fraction which, together with the low OM content of the GW composts (average $27 \%$ OM), points to an abundance of soil mineral particles in GW composts originating from garden waste including roots and associated soil. Hence, the origin of the Fe in composts differs from that in SFs of digestate. VFG composts are, in terms of P speciation, in between GW compost and SFs of digestate with $35 \%$ of $\mathrm{P}_{\mathrm{t}}$ being bound to $\mathrm{Fe} / \mathrm{Al}$-oxides.

Organic $P$ made up a relatively small fraction of $P_{t}(0.6-21 \%)$, which is because part of the OM has already been mineralised during anaerobic digestion and/composting. The remaining fraction of organic P may be released over time, depending on the mineralisation rate of the organic fraction. The rate of this process depends amongst others on the nature of the OM in the SOF [44] and the mineralisation rates of OM, which are generally higher for SFs from digestate as compared to composts [47]. Organic matter decomposition may also influence the release of $\mathrm{P}$ bound to $\mathrm{Fe} / \mathrm{Al}$ oxides by releasing organic acids which decrease $\mathrm{P}$ adsorption onto Fe/Al-oxides due to competition for absorption sites $[19,35,36]$, though this effect is likely small considering that Fe/Al-oxides in soils are usually already, to an extent, covered by organic matter [67].

Upon addition of an SOF to soil, $\mathrm{P}_{\mathrm{Fe}}$ present in the SOF might be slowly released over time due to desorption. The Langmuir equation can be used to describe the concentration of $\mathrm{P}_{-} \mathrm{PO}_{4}$ in equilibrium with $\mathrm{P}$ absorbed to Fe-oxides. The desorption rate is a function of the difference between the actual $\mathrm{P}_{-} \mathrm{PO}_{4}$ concentration in the soil solution and the equilibrium $\mathrm{P}_{-} \mathrm{PO}_{4}$ concentration. Hence, in soils with a low $\mathrm{P}$ status, $\mathrm{P}_{\mathrm{Fe}}$ will be slowly released and be partly reabsorbed onto the mineral surfaces of the receiving soil until a new equilibrium has been established. In soils with a high P status, meaning a high DPS, Fe-bound P present in SOFs adds to the total $\mathrm{P}$ stock in the soil but does not exert an effect on the $\mathrm{P}-\mathrm{PO}_{4}$ equilibrium concentration in the soil solution. This implies that the use of SOFs in which a large fraction of $\mathrm{P}$ is bound to $\mathrm{Fe} / \mathrm{Al}$ oxides at $\mathrm{P}$ application rates above crop uptake, is not likely to increase the risk of $\mathrm{P}$ leaching; but will also not increase the labile $\mathrm{P}$ available for plant uptake. Solid organic fertilisers with a large fraction of $\mathrm{P}$ bound to Fe/ $\mathrm{Al}$ oxides 
are, therefore, the preferred option for use as organic soil improvers since more OM can be added to the soil without increasing the risks for P leaching.

\section{Conclusions}

Our results provide further evidence that organic fertilisers recovered from digestate or biowaste are highly variable in terms of their $\mathrm{P}_{\mathrm{t}}$ content and $\mathrm{P}$ fertilising potential. Albeit tedious and time-consuming, the novel method presented here, which is based on $\mathrm{CaCl}_{2}$ extraction at $\mathrm{pH} 5.5$ and at a fixed total $\mathrm{P}$ content, provides a reliable means for assessing $\mathrm{P}$ availability. Easily available $\mathrm{P}$ correlated negatively with the fraction of $\mathrm{P}$ bound to $\mathrm{Fe} / \mathrm{Al}$ oxides $\left(\mathrm{P}_{\mathrm{Fe}}\right)$ determined from the oxalate-extractable $\mathrm{Fe}, \mathrm{Al}$, and $\mathrm{P}$. As such, $\mathrm{P}_{\mathrm{Fe}}$ could serve as an indicator for $\mathrm{P}$ availability in SOFs. Also, the relationship between easily available $\mathrm{P}$ and $\mathrm{P}_{\mathrm{Fe}}$ revealed that the use of $\mathrm{Fe}$ salts or Fe sludge negatively affects the availability of $\mathrm{P}$ in SFs of digestate and should, therefore, be discouraged. Generally, the fraction of easily available $\mathrm{P}$ was higher for SFs of digestate as compared to composted biowaste. When selecting organic $\mathrm{P}$ fertilisers or soil improver, farmers should be made aware of differences in $\mathrm{P}$ speciation among SOFs. SOFs with a high fraction of easily available $\mathrm{P}$, typically SFs of digestate, are preferably used as $\mathrm{P}$ fertilisers to raise the soil P status. Meanwhile, SOFs with a low fraction of easily available $\mathrm{P}$ act as slow-release fertilisers and are, therefore, the preferred choice in soils prone to $P$ leaching.

Supplementary Materials: The following are available online at https://www.mdpi.com/article/ 10.3390/agronomy11112233/s1, Table S1: Experimental parameters and composition of the $\mathrm{CaCl}_{2}$ extract solution at the initial $\mathrm{pH}$, Table S2: Experimental parameters and composition of the $\mathrm{CaCl}_{2}$ extract $30 \mathrm{~min}$ after lowering the $\mathrm{pH}$ towards 5.0.

Author Contributions: Conceptualization, I.C.R. and C.E.E.; methodology, I.C.R.; software, C.E.E.; validation, I.C.R. and C.E.E.; formal analysis, I.C.R. and C.E.E.; investigation, I.C.R. and C.E.E.; resources, I.C.R.; data curation, C.E.E. and I.C.R.; writing—original draft preparation, C.E.E. and I.C.R.; writing-review and editing, I.C.R., E.M., F.M.G.T. and C.E.E.; visualization, C.E.E.; supervision, F.M.G.T. and E.M.; project administration, E.M. and F.M.G.T.; funding acquisition, E.M., F.M.G.T. and I.C.R. All authors have read and agreed to the published version of the manuscript.

Funding: This research is done as part of the SYSTEMIC project that receives funding from the European Union's Horizon 2020 Framework Programme for Research and Innovation under Grant Agreement no. 730400 .

Institutional Review Board Statement: Not applicable.

Informed Consent Statement: Not applicable.

Data Availability Statement: All data generated or analysed during this study are included in the present article.

Conflicts of Interest: The authors declare no conflict of interest. The funders had no role in the design of the study; in the collection, analyses, or interpretation of data; in the writing of the manuscript, or in the decision to publish the results.

\section{References}

1. Khanzada, Z.T. Phosphorus removal from landfill leachate by microalgae. Biotechnol. Rep. 2020, 25, e00419. [CrossRef]

2. Wellmer, F.-W.; Scholz, R.W. The Right to Know the Geopotential of Minerals for Ensuring Food Supply Security: The Case of Phosphorus. J. Ind. Ecol. 2015, 19, 3-6. [CrossRef]

3. Reijnders, L. Phosphorus resources, their depletion and conservation, a review. Resour. Conserv. Recycl. 2014, 93, 32-49. [CrossRef]

4. van Dijk, K.C.; Lesschen, J.P.; Oenema, O. Phosphorus flows and balances of the European Union Member States. Sci. Total. Environ. 2016, 542, 1078-1093. [CrossRef]

5. Christel, W.; Bruun, S.; Magid, J.; Jensen, L.S. Phosphorus availability from the solid fraction of pig slurry is altered by composting or thermal treatment. Bioresour. Technol. 2014, 169, 543-551. [CrossRef]

6. Vaneeckhaute, C.; Janda, J.; Meers, E.; Tack, F.M.G. Efficiency of soil and fertilizer phosphorus use in time: A comparison between recovered struvite, FePO4-sludge, digestate, animal manure, and synthetic fertilizer. In Nutrient Use Efficiency: From Basics to Advance; Rakshit, A., Singh, H.B., Sen, A., Eds.; Springer: Berlin/Heidelberg, Germany, 2015; pp. 1-417, ISBN 9788132221692. 
7. Grigatti, M.; Boanini, E.; Cavani, L.; Ciavatta, C.; Marzadori, C. Phosphorus in Digestate-Based Compost: Chemical Speciation and Plant-Availability. Waste Biomass Valorization 2015, 6, 481-493. [CrossRef]

8. Möller, K.; Müller, T. Effects of anaerobic digestion on digestate nutrient availability and crop growth: A review. Eng. Life Sci. 2012, 12, 242-257. [CrossRef]

9. Vaneeckhaute, C.; Janda, J.; Vanrolleghem, P.A.; Tack, F.M.; Meers, E. Phosphorus Use Efficiency of Bio-Based Fertilizers: Bioavailability and Fractionation. Pedosphere 2016, 26, 310-325. [CrossRef]

10. Gagnon, B.; Demers, I.; Ziadi, N.; Chantigny, M.H.; Parent, L.-É.; Forge, T.A.; Larney, F.J.; Buckley, K.E. Forms of phosphorus in composts and in compost-amended soils following incubation. Can. J. Soil Sci. 2012, 92, 711-721. [CrossRef]

11. Grigatti, M.; Boanini, E.; Mancarella, S.; Simoni, A.; Centemero, M.; Veeken, A.H. Phosphorous extractability and ryegrass availability from bio-waste composts in a calcareous soil. Chemosphere 2017, 174, 722-731. [CrossRef]

12. Elliott, H.A.; O'Connor, G.A.; Brinton, S. Phosphorus Leaching from Biosolids-Amended Sandy Soils. J. Environ. Qual. 2002, 31, 681-689. [CrossRef]

13. Meyer, G.; Frossard, E.; Mäder, P.; Nanzer, S.; Randall, D.; Udert, K.M.; Oberson, A. Water soluble phosphate fertilizers for crops grown in calcareous soils-An outdated paradigm for recycled phosphorus fertilizers? Plant Soil 2018, 424, 367-388. [CrossRef]

14. Vogel, T.; Kruse, J.; Siebers, N.; Nelles, M.; Eichler-Löbermann, B. Recycled Products from Municipal Wastewater: Composition and Effects on Phosphorus Mobility in a Sandy Soil. J. Environ. Qual. 2017, 46, 443-451. [CrossRef] [PubMed]

15. Nest, T.V.; Amery, F.; Fryda, L.; Boogaerts, C.; Bilbao, J.; Vandecasteele, B. Renewable P sources: P use efficiency of digestate, processed animal manure, compost, biochar and struvite. Sci. Total. Environ. 2021, 750, 141699. [CrossRef]

16. Talboys, P.J.; Heppell, J.; Roose, T.; Healey, J.; Jones, D.; A Withers, P.J. Struvite: A slow-release fertiliser for sustainable phosphorus management? Plant Soil 2016, 401, 109-123. [CrossRef]

17. Gu, C.; Zhou, Q.; Cusick, R.D.; Margenot, A.J. Evaluating agronomic soil phosphorus tests for soils amended with struvite. Geoderma 2021, 399, 115093. [CrossRef]

18. Wilfert, P.; Kumar, P.S.; Korving, L.; Witkamp, G.-J.; van Loosdrecht, M. The Relevance of Phosphorus and Iron Chemistry to the Recovery of Phosphorus from Wastewater: A Review. Environ. Sci. Technol. 2015, 49, 9400-9414. [CrossRef]

19. Holford, I.C.R. Soil phosphorus: Its measurement, and its uptake by plants. Soil Res. 1997, 35, 227. [CrossRef]

20. Sánchez-Alcalá, I.; del Campillo, M.C.; Torrent, J. Critical Olsen P and CaCl2-P levels as related to soil properties: Results from micropot experiments. Soil Use Manag. 2015, 31, 233-240. [CrossRef]

21. Chinault, S.L.; O'Connor, G.A. Phosphorus Release from a Biosolids-Amended Sandy Spodosol. J. Environ. Qual. 2008, 37, 937-943. [CrossRef] [PubMed]

22. Cherosky, P.; Li, Y. Hydrogen sulfide removal from biogas by bio-based iron sponge. Biosyst. Eng. 2013, 114, 55-59. [CrossRef]

23. Øgaard, A.F.; Brod, E. Efficient Phosphorus Cycling in Food Production: Predicting the Phosphorus Fertilization Effect of Sludge from Chemical Wastewater Treatment. J. Agric. Food Chem. 2016, 64, 4821-4829. [CrossRef]

24. Schwertmann, U. Differenzierung der Eisenoxide des Bodens durch Extraktion mit Ammoniumoxalat-Lösung. Z. Für Pflanz. Düngung Bodenkd. 1964, 105, 194-202. [CrossRef]

25. Ayenew, B.; Taddesse, A.M.; Kibret, K.; Melese, A. Chemical forms of phosphorous and physicochemical properties of acid soils of Cheha and Dinsho districts, southern highlands of Ethiopia. Environ. Syst. Res. 2018, 7, 15. [CrossRef]

26. Guo, F.; Yost, R.S. Quantifying the Available Soil Phosphorus Pool with the Acid Ammonium Oxalate Method. Soil Sci. Soc. Am. J. 1999, 63, 651-656. [CrossRef]

27. Maguire, R.O.; Sims, J.T.; Coale, F.J. Phosphorus Solubility in Biosolids-Amended Farm Soils in the Mid-Atlantic Region of the USA. J. Environ. Qual. 2000, 29, 1225-1233. [CrossRef]

28. Warrinnier, R.; Goossens, T.; Amery, F.; Nest, T.V.; Verbeeck, M.; Smolders, E. Investigation on the control of phosphate leaching by sorption and colloidal transport: Column studies and multi-surface complexation modelling. Appl. Geochem. 2019, 100, 371-379. [CrossRef]

29. Elliot, H.A.; Potter, J.M.; Kang, J.; Brandt, R.C.; O'Connor, G.A. Neutral Ammonium Citrate Extraction of Biosolids Phosphorus. Commun. Soil Sci. Plant Anal. 2005, 36, 2447-2459. [CrossRef]

30. Janßen, E. Extraction of Soluble Phosphorus in Soil, Sludge, Biowaste and Treated Biowaste; Horizontal-25; Giessen: Frankfurt, German, 2004; pp. 1-18. Available online: https://horizontal.ecn.nl/docs/society/horizontal/hor_desk_25_solubleP_revised. pdf (accessed on 25 April 2021).

31. Houba, V.J.G.; Novozamsky, I.; Lexmond, T.M.; Van Der Lee, J.J. Applicability of $0.01 \mathrm{M} \mathrm{CaCl2}$ as a single extraction solution for the assessment of the nutrient status of soils and other diagnostic purposes. Commun. Soil Sci. Plant Anal. 1990, 21, 2281-2290. [CrossRef]

32. Kratz, S.; Schick, J.; Øgaard, A.F. P Solubility of Inorganic and Organic P Sources. In Phosphorus in Agriculture: 100\% Zero; Schnug, E., De Kok, L.J., Eds.; Springer: Dordrecht, The Netherlands, 2016; pp. 1-926, ISBN 9789401776127.

33. Idowu, M.K.; Ige, D.V.; O Akinremi, O. Elution of inorganic and organic phosphorus from surface applied organic amendments. Can. J. Soil Sci. 2008, 88, 709-718. [CrossRef]

34. Iyamuremye, F.; Dick, R.P.; Baham, J. Organic Amendments and Phosphorus Dynamics: I. Phosphorus Chemistry and Sorption. Soil Sci. 1996, 161, 426-435. [CrossRef]

35. Siddique, M.T.; Robinson, J.S. Phosphorus Sorption and Availability in Soils Amended with Animal Manures and Sewage Sludge. J. Environ. Qual. 2003, 32, 1114-1121. [CrossRef] 
36. Nest, T.V.; Ruysschaert, G.; Vandecasteele, B.; Houot, S.; Baken, S.; Smolders, E.; Cougnon, M.; Reheul, D.; Merckx, R. The long term use of farmyard manure and compost: Effects on $\mathrm{P}$ availability, orthophosphate sorption strength and P leaching. Agric. Ecosyst. Environ. 2016, 216, 23-33. [CrossRef]

37. Brod, E.; Øgaard, A.F.; Hansen, E.; Wragg, D.; Haraldsen, T.K.; Krogstad, T. Waste products as alternative phosphorus fertilisers part I: Inorganic P species affect fertilisation effects depending on soil pH. Nutr. Cycl. Agroecosystems 2015, 103, 167-185. [CrossRef]

38. Biowaste Solution-SYSTEMIC European Union Project. Available online: www.systemicproject.eu (accessed on 5 May 2021).

39. Brienza, C.; Sigurnjak, I.; Meier, T.; Michels, E.; Adani, F.; Schoumans, O.; Vaneeckhaute, C.; Meers, E. Techno-economic assessment at full scale of a biogas refinery plant receiving nitrogen rich feedstock and producing renewable energy and biobased fertilisers. J. Clean. Prod. 2021, 308, 127408. [CrossRef] [PubMed]

40. Fertimanure. Available online: www.fertimanure.eu (accessed on 5 May 2021).

41. EN13650. Soil Improvers and Growing Media Extraction of Aqua Regia Soluble Elements; BSI: London, UK, 2001.

42. EN13654-1. Soil Improvers and Growing Media-Determination of Nitrogen—Part 1: Modified Kjeldahl Method; CEN: Brussels, Belgium, 2002.

43. Houba, V.; Lexmond, T.; Novozamsky, I.; van der Lee, J. State of the art and future developments in soil analysis for bioavailability assessment. Sci. Total. Environ. 1996, 178, 21-28. [CrossRef]

44. Kuo, S. Phosphorus. In Methods of Soil Analysis; Sparks, D.L., Ed.; Agronomy 9; ASA-SSSA: Madison, WI, USA, 1996; pp. 1035-1049. ISBN 9780891182047.

45. van Reeuwijk, L. Procedures for Soil Analysis, 6th ed.; ISRIC, FAO: Wageningen, The Netherlands, 2002.

46. Alburquerque, J.A.; de la Fuente, C.; Ferrer-Costa, A.; Carrasco, L.; Cegarra, J.; Abad, M.; Bernal, M.P. Assessment of the fertiliser potential of digestates from farm and agroindustrial residues. Biomass Bioenergy 2012, 40, 181-189. [CrossRef]

47. Egene, C.E.; Sigurnjak, I.; Regelink, I.C.; Schoumans, O.F.; Adani, F.; Michels, E.; Sleutel, S.; Tack, F.M.G.; Meers, E. Solid fraction of separated digestate as soil improver: Implications for soil fertility and carbon sequestration. J. Soils Sediments 2021, 21, 678-688. [CrossRef]

48. Prasad, M. A Literature Review on the Availability of Phosphorus from Compost in Relation to the Nitrate Regulations SI 378 of 2006 ; Environmental Protection Agency: Wexford, Ireland, 2013.

49. Kern, J.; Heinzmann, B.; Markus, B.; Kaufmann, A.C.; Soethe, N.; Engels, C. Recycling and Assessment of Struvite Phosphorus from Sewage Sludge. Agric. Eng. Int. CIGR J. 2008, 10, 13.

50. Ehlert, P.; van Middelkoop, J.; van Geel, W.; de Haan, J.; Regelink, I.C. Veeljarige Fosfaatveldproeven op Gras- en Bouwland; Wageningen, The Netherland, 2018; p. 114. Available online: https: / / edepot.wur.nl/460816 (accessed on 5 June 2021).

51. Güsewell, S. N : P ratios in terrestrial plants: Variation and functional significance. N. Phytol. 2004, 164, 243-266. [CrossRef] [PubMed]

52. García-Albacete, M.; Martín, A.; Cartagena, M.C. Fractionation of phosphorus biowastes: Characterisation and environmental risk. Waste Manag. 2012, 32, 1061-1068. [CrossRef] [PubMed]

53. Dormaar, J.F.; Webster, G.R. Losses Inherent in Ignition Procedures for Determining Total Organic Phosphorus. Can. J. Soil Sci. 1964, 44, 1-6. [CrossRef]

54. Williams, J.D.H.; Syers, J.K.; Walker, T.W.; Rex, R.W. A comparison of methods for the determination of soil organic phosphorus. Soil Sci. 1970, 110, 13-18. [CrossRef]

55. Koopmans, G.F.; Chardon, W.; Ehlert, P.A.I.; Dolfing, J.; Suurs, R.A.A.; Oenema, O.; Van Riemsdijk, W.H. Phosphorus Availability for Plant Uptake in a Phosphorus-Enriched Noncalcareous Sandy Soil. J. Environ. Qual. 2004, 33, 965-975. [CrossRef]

56. Gasparatos, D.; Haidouti, C.; Haroulis, A.; Tsaousidou, P. Estimation of Phosphorus Status of Soil Fe-Enriched Concretions with the Acid Ammonium Oxalate Method. Commun. Soil Sci. Plant Anal. 2006, 37, 2375-2387. [CrossRef]

57. Gustafsson, J.P. Modelling competitive anion adsorption on oxide minerals and an allophane-containing soil. Eur. J. Soil Sci. 2001, 52, 639-653. [CrossRef]

58. Van Der Zee, S.E.A.T.M.; Fokkink, L.G.J.; Van Riemsdijk, W.H. A New Technique for Assessment of Reversibly Adsorbed Phosphate. Soil Sci. Soc. Am. J. 1987, 51, 599-604. [CrossRef]

59. Van Der Zee, S.; Van Riemsdijk, W. Sorption kinetics and transport of phosphate in sandy soil. Geoderma 1986, 38, 293-309. [CrossRef]

60. Hylander, L.D.; Svensson, H.; Siman, G. Different methods for determination of plant available soil phosphorus. Commun. Soil Sci. Plant Anal. 1996, 27, 1501-1512. [CrossRef]

61. Dail, H.W.; He, Z.; Erich, M.S.; Honeycutt, C.W. Effect of Drying on Phosphorus Distribution in Poultry Manure. Commun. Soil Sci. Plant Anal. 2007, 38, 1879-1895. [CrossRef]

62. Achat, D.L.; Augusto, L.; Gallet-Budynek, A.; Bakker, M.R. Drying-induced changes in phosphorus status of soils with contrasting soil organic matter contents-Implications for laboratory approaches. Geoderma 2012, 187-188, 41-48. [CrossRef]

63. Weng, L.; Vega, F.A.; Van Riemsdijk, W.H. Competitive and Synergistic Effects in pH Dependent Phosphate Adsorption in Soils: LCD Modeling. Environ. Sci. Technol. 2011, 45, 8420-8428. [CrossRef] [PubMed]

64. Yaron, B.; Calvet, R.; Prost, R. The Soil Pollutants. In Soil Pollution: Processes and Dynamics; Springer: Berlin/Heidelberg, Germany, 1996; pp. 25-53.

65. Roboredo, M.; Fangueiro, D.; Lage, S.; Coutinho, J. Phosphorus dynamics in soils amended with acidified pig slurry and derived solid fraction. Geoderma 2012, 189-190, 328-333. [CrossRef] 
66. Costa, C.; Cornacchia, M.; Pagliero, M.; Fabiano, B.; Vocciante, M.; Reverberi, A. Hydrogen Sulfide Adsorption by Iron Oxides and Their Polymer Composites: A Case-Study Application to Biogas Purification. Materials 2020, 13, 4725. [CrossRef] [PubMed]

67. Hiemstra, T.; Antelo, J.; van Rotterdam, A.; van Riemsdijk, W.H. Nanoparticles in natural systems II: The natural oxide fraction at interaction with natural organic matter and phosphate. Geochim. Cosmochim. Acta 2010, 74, 59-69. [CrossRef] 